\title{
A new synthesis of $\boldsymbol{N}$-heteroaromatic compounds via cyclocarbonylative Sonogashira reactions
}

\author{
Laura Antonella Aronica $^{*[a]}$, Gianluigi Albano ${ }^{[a]}$, Luca Giannotti ${ }^{[a]}$ and Elisa Meucci ${ }^{[a]}$
}

Abstract: In this study, a protocol based on cyclocarbonylative Sonogashira reactions has been developed for the synthesis of $\mathrm{N}$-containing heterocycles. The process is carried out under $\mathrm{CO}$ pressure, in the presence of a small amount of $\mathrm{PdCl}_{2}\left(\mathrm{PPh}_{3}\right)_{2}$ (0.2-0.4 mol\%) as catalytic precursor and without copper salts as co-catalyst. Suitable tosylamides reacted successfully with iodoarenes bearing both electron withdrawing and electron donating groups. In particular $\mathrm{N}$-(2-ethynylbenzyl)-4methylbenzenesulfonamide afforded carbonylmethylene isoindolines with complete chemo-stereoselectivity. On the other hand, the reaction between iodoarenes and $\mathrm{N}-(2-$ ethynylphenethyl)-4-methylbenzenesulfonamide did not yield tetrahydroisoquinolines as expected, but dihydrobenzoazepines were obtained.

\section{Introduction}

The chemistry of heterocycles has attracted much attention in recent times due to its increasing importance in the field of pharmaceuticals and industrial chemicals. In particular, $\mathrm{N}$ containing heterocycles are important substructures found in numerous natural or synthetic alkaloids ${ }^{[1]}$ and are the basis for industrial applications such as pigments, brighteners for coatings and organic fluorophors for electrolumiscent devices ${ }^{[2]}$.

Therefore, several procedures dedicated to the construction of such heterocycles have been developed. Many of them are based on cyclization of suitable substrates. For instance indole derivatives (Figure 1, a) can be generated ${ }^{[3]}$ via multicomponent processes, transition metal-catalysed intramolecular $\mathrm{C}-\mathrm{H}$ activation, hydroamination of alkynes and cyclisation of alkynylanilines. On the other hand isoindoles (Figure 1, b) can be obtained ${ }^{[4]}$ by means of cycloisomerization reactions and 1,3dipolar cycloadditions of azides, nitrogen ylides or isocyanides. The hydrogenated analogue of isoindole is isoindoline, whose scaffold (Figure 1, c) represents a useful building block for the synthesis of biologically active compounds ${ }^{[5]}$. Isoindolines may be prepared ${ }^{[6]}$ starting from chalcones and glycine through a cascade process involving aza-Michael addition and decarboxylation steps, via $[2+2+2]$ cycloaddition reactions of suitable alkynes and diyines and by TBAF promoted cyclisation of ethynylbenzylamine derivatives.

Recently we reported ${ }^{[7]}$ that 1,3-dihydroisobenzofuranes and isochromanes can be easily obtained starting from suitable alkynylalcohols via cyclocarbonylative Sonogashira reaction

[a] Dipartimento di Chimica e Chimica Industriale University of Pisa

Via G. Moruzzi 13, 56124 Pisa, Italy

Fax: (+)390502219260

E-mail: laura.antonella.aronica@unipi.it

Supporting information for this article is given via a link at the end of the document

(Scheme 1).

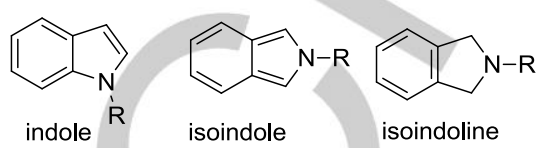

(a)

(b)

(c)

Figure 1. Indole, isoindole and isoindoline scaffolds.

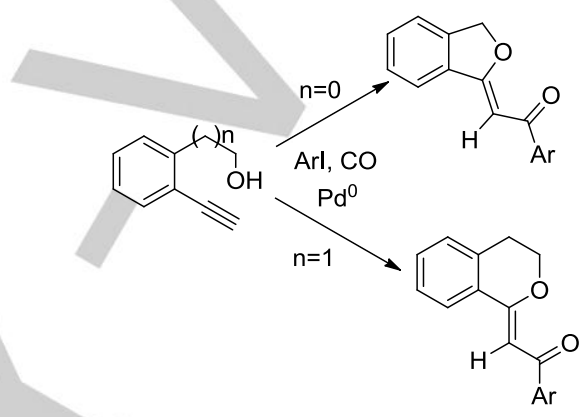

Scheme 1. Synthesis of dihydroisobenzofuranes and isochromanes.

In this paper we present an extension of our protocol to benzylic and homobenzylic amines in order to investigate the application of this method to the synthesis of $\mathrm{N}$-containing heterocycles such as isoindolines and tetrahydroisoquinolines (Scheme 2).

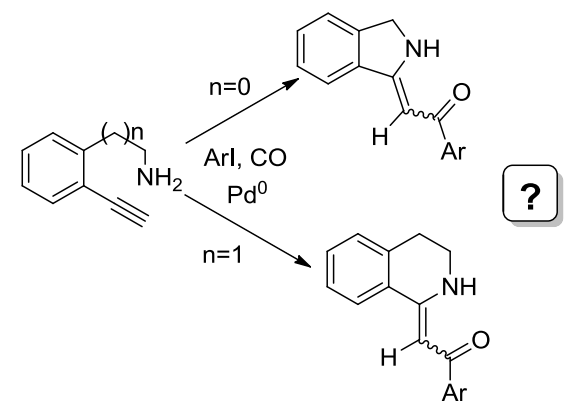

Scheme 2. Possible synthesis of isoindolines and tetrahydroisoquinolines.

\section{Results and Discussion}

We started our study with the synthesis of (2ethynylphenyl)methanamine (1) which was obtained according to the sequence depicted in Scheme 3. Commercially available 2-iodobenzonitrile (2) was submitted to a Sonogashira reaction with trimethylsilylacetylene affording the coupling product $\mathbf{3}$ in high yield. Subsequent desilylation and reduction of the nitrile moiety generated the desired product 1 . 


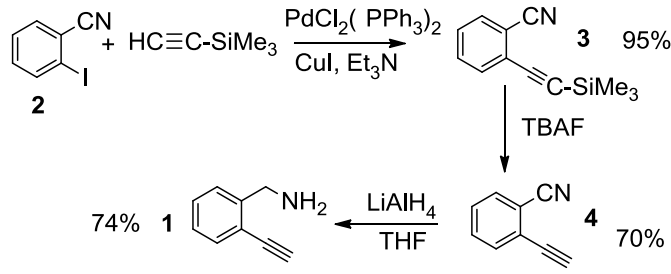

Scheme 3. Synthesis of (2-ethynylphenyl)methanamine (1)

Unfortunately, when ethynylbenzylamine 1 was reacted with iodobenzene (5a) under cyclocarbonylative Sonogashira isoindoline derivative was obtained (Scheme 4), even if a total consumption of both reagents was observed together with the formation of significant amounts of unidentified by-products.

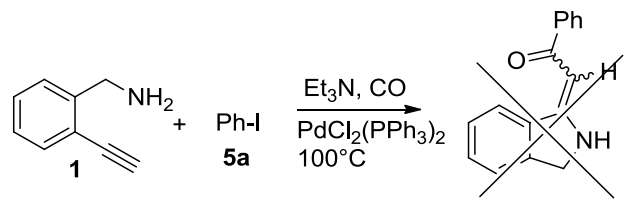

Scheme 4. Reaction of (2-ethynylphenyl)methanamine (1) with iodobenzene (5a) under Sonogashira cyclocarbonylative conditions. experimental conditions $\left(\mathrm{CO}, \mathrm{PdCl}_{2}\left(\mathrm{PPh}_{3}\right)_{2}, \mathrm{Et}_{3} \mathrm{~N}, 100^{\circ} \mathrm{C}\right)^{[7]}$ no

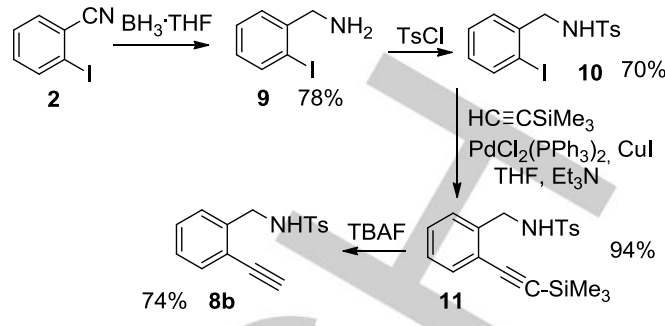

Scheme 6. Synthesis of $N$-(2-ethynylbenzyl)-4-methylbenzenesulfonamide (8b).

A preliminary cyclocarbonylative Sonogashira reaction was performed reacting tert-butyl 2-ethynylbenzylcarbamate (8a) with iodobenzene $(5 \mathrm{a})$ in a triethylamine/toluene mixture, at $100^{\circ} \mathrm{C}$, with $\mathrm{PdCl}_{2}\left(\mathrm{PPh}_{3}\right)_{2}(0.2 \mathrm{~mol} \%)$ and under 20 atmosphere of $\mathrm{CO}$ (Scheme 7, Table 1 entry 1 ). After $4 \mathrm{~h}$, a complete consumption of the reagents was observed but ${ }^{1} \mathrm{H}-\mathrm{NMR}$ analysis highlighted the formation of two different products in a 19/81 ratio. Indeed, after purification isoindoline 12aa was isolated with a $14 \%$ yield, while tert-butyl 2-(3-oxo-3-phenylprop-1-yn-1yl)benzylcarbamate (13) resulted to be the principal product (Scheme 7, 49\%), deriving from carbonylative Sonogashira coupling between iodobenzene $(\mathbf{5 a})$ and the alkynyl moiety of amide $8 \mathbf{a}$ before cyclization ${ }^{[7]}$

This result could tentatively be ascribed to a chemical instability of the isoindoline derivative under the experimental conditions or to a possible interaction between $\mathrm{NH}_{2}$ moiety and palladium complex which could change its catalytic activity. In order to avoid these side effects, we decided to protect the amine 1 with tert-butylcarbamoyl and tosyl groups. The corresponding amides were easily synthesized starting from commercial precursors $\mathrm{N}$ Boc-2-bromobenzylamine (6) and 2-iodonitrile (2) as described in Schemes 5 and 6 respectively. Indeed, $N$-Boc-2bromobenzylamine (6) was coupled with trimethylsilylacetylene generating intermediate 7 which was then desilylated by means of tetrabutylamonium fluoride affording $\mathrm{N}$-BOC amide $\mathbf{8 a}$ (Scheme 5).

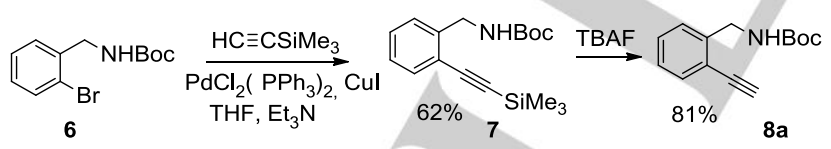

Scheme 5. Synthesis of tert-butyl 2-ethynylbenzylcarbamate (8a).

Reduction of 2-iodonitrile 2 treatment of the obtained benzylamine $\mathbf{9}$ with $p$-toluenesulphonyl chloride and Sonogashira-desilylation sequence performed on tosylamide $\mathbf{1 0}$ afforded $\mathrm{N}$-(2-ethynylbenzyl)-4-methyl benzenesulfonamide (8b) in good yield (Scheme 6).

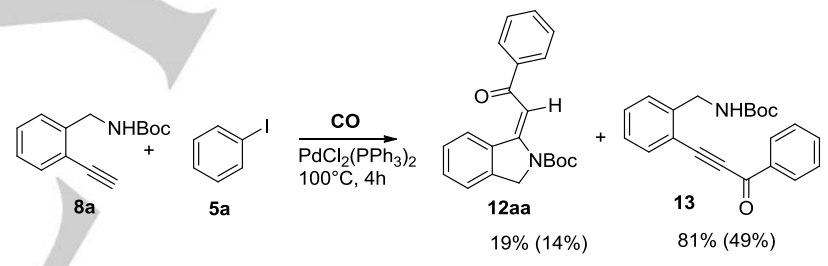

Scheme 7. Cyclocarbonylative reaction of tert-butyl 2-ethynylbenzylcarbamate (8a).

Even though Baldwin's rules ${ }^{[8]}$ allow the formation of both 5-exodig and 6-endo-dig derivatives, no traces of the possible dihydroisoquinoline were detected. Moreover, the formation of the five-membered isoindoline 12aa resulted totally stereoselective, i.e. only the $E$ isomer was obtained. According to our previous work on the cyclocarbonylative reactions of ethynylbenzylalcohols, the configuration of 12aa was determined by means of the analysis of its ${ }^{1} \mathrm{H}$-NMR spectrum. Indeed, proton $H_{a}$ was found at an unusually high chemical shift $(9.08$ $\mathrm{ppm})$, due to its strong interaction with the carbonyl deshielding cone (Figure 2). 


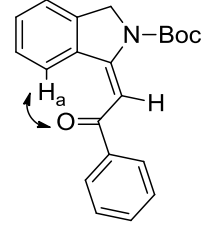

Figure 2. $E$ configuration of tert-butyl 1-(2-oxo-2-phenylethylidene)isoindoline2-carboxylate (12aa)

When the cyclocarbonylative reaction of amide $\mathbf{8 a}$ with iodobenzene (5a) was carried out for a longer reaction time (24h), higher chemoselectivity towards the cyclization product 12aa was observed (86\%, Table 1, entry 2$)$.

Table 1. Cyclocarbonylative Sonogashira reactions of amides 8 and aryliodides 5 .

\begin{tabular}{|c|c|c|c|c|c|c|c|}
\hline Entry ${ }^{[a]}$ & $\mathrm{Ar}$ & 5 & $X$ & 8 & $\begin{array}{l}\mathrm{t} \\
\text { (h) }\end{array}$ & 12 & Selectivity ${ }^{[b]}$ \\
\hline 1 & $\mathrm{Ph}$ & a & Boc & a & 4 & aa & $19(14)$ \\
\hline 2 & $\mathrm{Ph}$ & a & Boc & a & 24 & aa & 86 \\
\hline 3 & $\mathrm{Ph}$ & a & $p$-Ts & b & 24 & $a b$ & $100(72)$ \\
\hline 4 & $\mathrm{Ph}$ & a & $p$-Ts & b & 8 & $a b$ & 100 \\
\hline 5 & $\mathrm{Ph}$ & a & $p$-Ts & b & 4 & $a b$ & 100 \\
\hline 6 & $\mathrm{Ph}$ & a & $p-T s$ & b & 2 & $a b$ & 100 \\
\hline $7^{[c]}$ & 4- $\mathrm{MeOC}_{6} \mathrm{H}_{4}$ & b & $p$-Ts & b & 2 & bb & 100 \\
\hline 8 & 4- $\mathrm{MeOC}_{6} \mathrm{H}_{4}$ & b & $p$-Ts & b & 4 & bb & $100(72)$ \\
\hline 9 & $4-\mathrm{ClC}_{6} \mathrm{H}_{4}$ & c & $p-T s$ & b & 4 & cb & $100(65)$ \\
\hline 10 & $4-\mathrm{NCC}_{6} \mathrm{H}_{4}$ & d & $p$-Ts & b & 4 & $\mathrm{db}$ & $100(60)$ \\
\hline 11 & 2-naphthyl & e & $p$-Ts & b & 4 & eb & $100(68)$ \\
\hline 12 & $2-\mathrm{MeOC}_{6} \mathrm{H}_{4}$ & f & $\mathrm{p}$-Ts & b & 4 & $\mathrm{fb}$ & $100(55)$ \\
\hline
\end{tabular}

[a] Reactions were carried out with 8 (0.5-1 mmol), 5 (0.6-1.2 mmol), $\mathrm{PdCl}_{2}\left(\mathrm{PPh}_{3}\right)_{2}(0.2 \mathrm{~mol} \%)$, in $\mathrm{Et}_{3} \mathrm{~N}(1.5-3 \mathrm{~mL})$ and toluene $(1-2 \mathrm{~mL})$, at $100^{\circ} \mathrm{C}$, under $\mathrm{CO}(2.0 \mathrm{MPa})$. Conversions $(100 \%$ unless otherwise specified) were evaluated by GC and ${ }^{1} \mathrm{H}$-NMR spectroscopic analysis. [b] Selectivity was estimated by ${ }^{1} \mathrm{H}$-NMR spectroscopy; isolated yields of pure products are reported in parentheses. [c] $60 \%$ conversion was observed in this run.

In order to verify if the results obtained with benzylcarbamate $\mathbf{8 a}$ could be ascribed to its steric hindrance, tosyl derivative $\mathbf{8 b}$ was tested under the same experimental conditions.
To our delight, the cyclocarbonylative Sonogashira reaction of 8b yielded quantitatively (E)-1-phenyl-2-(2-tosylisoindolin-1ylidene)ethanone (12ab) with complete stereoselectivity (Table 1, entry 3 ). Moreover, the reaction time could be reduced till $2 \mathrm{~h}$ without loss of conversion or selectivity (Table 1, entries 3-6).

On the contrary, the decrease of the temperature from 100 to $30^{\circ} \mathrm{C}$ resulted in a dramatic reduction of chemoselecivity. Indeed, in this case, a small quantity of the desired product 12ab was formed, together with a large amount of 4-methyl- $\mathrm{N}-(2-$ (phenylethynyl)benzyl)benzenesulfonamide (14) (Schema 8) derived from non carbonylative Sonogashira reaction of iodobenzene (5a) with tosylamide $\mathbf{8 b}$.

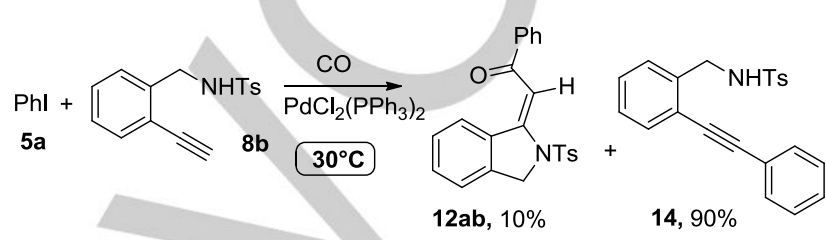

Scheme 8. Sonogashira cyclocarbonylative reaction of $\mathrm{N}$-(2-ethynylbenzyl)-4methylbenzenesulfonamide $(\mathbf{8 b})$ and iodobenzene $(5 \mathbf{a})$ at $30^{\circ} \mathrm{C}$.

As a consequence, $100^{\circ} \mathrm{C}$ was chosen as operation temperature and the cyclocarbonylation process was extended to iodoarenes 5 having both electron donating and electron withdrawing substituents in ortho or para position. As described in Table 1 (entries 8-12), a quantitative conversion of the reagents was detected in all experiments after $2-4 \mathrm{hs}$ and the reactions generated the isoindolines 12ab-fb with good yields $(55-72 \%$, not optimized) and complete stereoselectivity towards the formation of the $(E)$-isomer, regardless the stereo-electronic features of the aryl iodides employed.

Prompted by the good results obtained with the Sonogashira carbonylative reactions of ethynyl benzyl amide $\mathbf{8 b}$ and aryl iodides, we decided to extend our investigation to the reactivity of $\quad \mathrm{N}$-(2-ethynylphenethyl)-4-methylbenzenesulfonamide (15) (Figure 3).

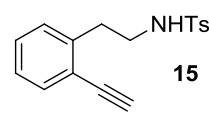

Figure 3. N-(2-ethynylphenethyl)-4-methylbenzenesulfonamide (15).

The homobenzylic amide $\mathbf{1 5}$ was easily prepared following the same synthetic sequence used for $\mathrm{N}$-(2-ethynylbenzyl)-4-methyl benzenesulfonamide (8b) (Scheme 9). Indeed, 2-(2lodophenyl)acetonitrile (16) was converted into the corresponding amine $\mathbf{1 7}$ which was then protected with the tosyl group affording N-(2-iodophenethyl)-4methylbenzenesulfonamide (18). Subsequent ethynylation/desilylation steps yielded amide 15 (70\%). 


$$
\text { (16) }
$$

Scheme 9. Synthesis of $\mathrm{N}$-(2-ethynylphenethyl)-4-methylbenzenesulfonamide (15)

A preliminary cyclocarbonylative Sonogashira reaction was methylbenzenesulfonamide (15) and iodobenzene (5a), under the experimental conditions previously optimised for the tosyl derivative 8 b, i.e. $20 \mathrm{~atm} \mathrm{CO}, 100^{\circ} \mathrm{C}, 0.2 \mathrm{~mol} \% \mathrm{PdCl}_{2}\left(\mathrm{PPh}_{3}\right)_{2}$, in a toluene-triethylamine mixture. After $4 \mathrm{~h}$, the ${ }^{1} \mathrm{H}-\mathrm{NMR}$ analysis of the crude product indicated a complete conversion of the reagents and the formation of three main compounds. In particular, ${ }^{13} \mathrm{C}$-NMR spectrum showed the signals of three $\mathrm{CO}$ groups $(177.69,191.28,193.28 \mathrm{ppm})$ together with those of two acetylenic carbon atoms $(90.77,91.18 \mathrm{ppm})$. When the crude product was purified by means of silica gel column chromatography, a partial decomposition occurred, but small amounts of the products were obtained. First, 4-methyl- $\mathrm{N}-(2-(3-$ oxo-3-phenylprop-1-yn-1-yl)phenethyl)benzenesulfonamide (20) (Figure 4), deriving from carbonylative Sonogashira reaction (see also Scheme 7) was isolated, thus confirming the observed ${ }^{13} \mathrm{C}-\mathrm{NMR} \mathrm{C}=\mathrm{O}$ and $\mathrm{C} \equiv \mathrm{C}$ signals.

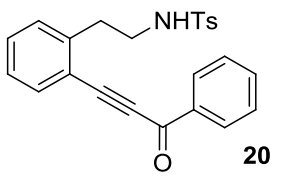

Figure 4. 4-methyl- $\mathrm{N}$-(2-(3-oxo-3-phenylprop-1-yn-1yl)phenethyl)benzenesulfonamide (20).

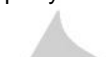

The analysis of ${ }^{1} \mathrm{H}-\mathrm{NMR},{ }^{13} \mathrm{C}-\mathrm{NMR}$ and LC-MS spectra of a second chromatographic fraction indicated the unexpected formation of phenyl(3-tosyl-2,3-dihydro-1 H-benzo[d]azepin-4$\mathrm{yl}$ )methanone (21a) as a mixture of two conformational isomers (s-trans and s-cis). Under the spectra recording conditions $\left(20^{\circ} \mathrm{C}\right.$ $\mathrm{CDCl}_{3}$ ), the interconversion equilibrium of these compounds was shifted towards the s-trans conformer (60/40, Scheme 10). This result was in agreement with molecular mechanics calculations (MMFF as a force field) that predicted higher energy for the $s$-cis isomer $(+0.5 \mathrm{Kcal} / \mathrm{mol})$. The structure of both conformers was confirmed by ROESY (Rotating frame Overhauser Effect Spectroscopy) experiments which evidenced not only the correlation between vinylic $\mathrm{Ha}$, $\mathrm{Ha}$ and aromatic $\mathrm{Hb}, \mathrm{Hb}^{\prime}$ hydrogens (Scheme 10), but also the presence of cross peaks due to proton exchange of the two isomers.
It is noteworthy that the generation of the seven membered ring is permitted by Baldwin rules since a 7-endo-dig cyclisation is favored compared with the 6-exo-dig one ${ }^{[8]}$.

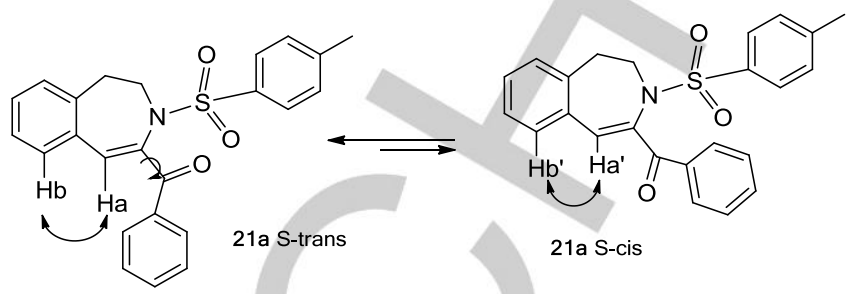

Scheme 10. Conformational isomers of phenyl(3-tosyl-2,3-dihydro-1 $\mathrm{H}$ benzo[d]azepin-4-yl)methanone (21a)

The serendipitous formation of the dihydrobenzoazepine derivatives was extremely interesting considering that these substrates could be precursors to the corresponding tetrahydrobenzoazepines which have been studied for more than 30 years due to their very important biological and pharmacological properties ${ }^{[0]}$.

A few tests reacting $\mathrm{N}$-(2-ethynylphenethyl)-4methylbenzenesulfonamide (15) with iodobenzene (5a) under different experimental conditions have been performed in order to optimise the chemoselectivity of the cyclocarbonylative Sonogashira process (Table 2).

Table 2. Cyclocarbonylative Sonogashira reactions between amide 15 and iodobenzene $(5 \mathbf{a})$.

\begin{tabular}{|c|c|c|c|c|}
\hline Entry $^{[\mathrm{a}]}$ & $\mathrm{Pd}(\mathrm{mol} \%)$ & $t(h)$ & $\mathrm{T}\left({ }^{\circ} \mathrm{C}\right)$ & $\begin{array}{l}\text { Selectivity }(\%)^{[\mathrm{b}]} \\
(\mathrm{s} \text {-trans/s-cis) }\end{array}$ \\
\hline 1 & 0.2 & 4 & 100 & $80^{[c]}(40 / 60)^{[d]}$ \\
\hline 2 & 0.4 & 4 & 100 & $91^{[c]}(64 / 36)$ \\
\hline $3^{[e]}$ & 0.4 & 6 & 100 & $93^{[c]}(65 / 35)$ \\
\hline 4 & 0.4 & 6 & 110 & $100(60 / 40)$ \\
\hline 5 & 0.4 & 24 & 50 & $68^{[\mathrm{c}]}(36 / 64)^{[\mathrm{d}]}$ \\
\hline 6 & 5 & 24 & 50 & $75^{[f]}(67 / 33)$ \\
\hline
\end{tabular}

[a] Reactions were performed with 15 (0.5-1 mmol), 5a (0.6-1.2 mmol), in $\mathrm{Et}_{3} \mathrm{~N}(1.5-3 \mathrm{~mL})$ and toluene (1-2 mL), under $\mathrm{CO}$ (2.0 MPa). [b] Selectivity was estimated by ${ }^{1} \mathrm{H}$-NMR spectroscopy of crude products; conformers ratio is reported in parentheses. [c] Remainder of product is 4-methyl- $N$ (2-(3-oxo-3-phenylprop-1-yn-1-yl)phenethyl)benzenesulfonamide (20). [d] After purification the conformer ratio resulted always around 60/40 ( $s$ trans/s-cis). [e] Reaction carried out under CO 4.0 MPa pressure. [f] Remainder of product is $20(15 \%)$ and $N^{\prime} N^{\prime}$-((buta-1,3-diyne-1,4diylbis(2,1-phenylene))bis(ethane-2,1-diyl))bis(4-

methylbenzenesulfonamide) (22). 
As reported in Table 2, all the reactions proceeded with complete conversion of the reagents, but a substantial increase of the selectivity was observed when a major amount of catalyst was employed (Table 2, entries 1,2). Longer reaction times or higher $\mathrm{CO}$ pressure did not improve effectively the reaction (Table 2, entry 3), while, when the cross coupling was performed at $110^{\circ} \mathrm{C}$ and in the presence of $0.4 \mathrm{~mol} \%$ of $\mathrm{PdCl}_{2}\left(\mathrm{PPh}_{3}\right)_{2},{ }^{1} \mathrm{H}-$ NMR analysis showed the exclusive formation of the two conformers of dihydrobenzoazepine 21a (Table 2, entry 4). The last result indicated an important effect of the temperature on the selectivity of the reaction. Two more tests were then carried out at $50^{\circ} \mathrm{C}$ but in both cases relevant amount of by-products were detected (Table 2, entries 5,6). In particular, not only the carbonylated derivative $\mathbf{2 0}$ was present in the reaction mixture but also the formation of $N, N^{\prime}$-((buta-1,3-diyne-1,4-diylbis(2,1phenylene))bis(ethane-2,1-diyl))bis(4-ethylbenzenesulfonamide) (22) was detected (Figure 5).

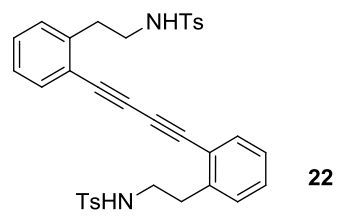

Figure 5. Glaser by-product $N, N^{\prime}-(($ buta-1,3-diyne-1,4-diylbis(2,1phenylene))bis(ethane-2,1-diyl))bis(4-methylbenzenesulfonamide) (22).

The structure of compound $\mathbf{2 2}$ could be explained with an oxidative homo-coupling process (i.e. Glaser reaction) of $\mathrm{N}$-(2ethynylphenethyl)-4-methylbenzenesulfonamide (15), probably favoured by low temperature condition and large quantity of catalyst ${ }^{[10]}$

Once we had found suitable experimental conditions to obtain exclusively dihydrobenzoazepine $\mathbf{2 1 a}$ (Table 2, entry 4), several efforts to purify the crude product were made. Column chromatography on neutral $(\mathrm{pH} 7)$ aluminum oxide ( $n$ hexane/AcOEt 3:1 as eluent) resulted the best methodology to isolate pure 21 a in satisfying yield $(52 \%)$.

The cyclocarbonylative Sonogashira reaction was then applied to iodoarenes with different steric and electronic features (Table $3)$. In all cases a quantitative conversion of the reagents was observed and the benzoazepine derivatives were obtained chemically pure with good yields $(46-65 \%)$. As is evident from Table 3, the chemoselectivity of the reaction was dependent on the nature of the functional group present on the benzene ring. Indeed, while methoxy or chloro derivatives (Table 3, entries 24) afforded exclusively dihydrobenzoazepine 21b, 21f and 21c, the coupling between 4-iodobenzonitrile $(5 \mathbf{d})$ and $\mathrm{N}-(2-$ ethynylphenethyl)-4-methylbenzenesulfonamide (15) yielded 21d together with by-products. After purification, $\mathrm{N}-(2-((4-$ cyanophenyl)ethynyl)phenethyl)-4-methylbenzenesulfonamide (23) (18\%) and (2,3-dihydro-1 H-benzo[d]azepin-4yl)(phenyl)methanone (24) (9\%, s-trans) were isolated and identified (Figure 6).
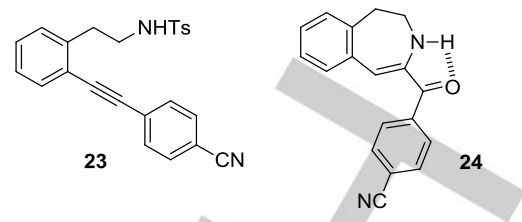

Figure 6. By-products generated in the reaction of 4-iodobenzonitrile $(\mathbf{5 d})$ with $\mathrm{N}$-(2-ethynylphenethyl)-4-methylbenzenesulfonamide (15).

The formation of $\mathbf{2 3}$ was easily ascribed to a direct Sonogashira reaction of tosylamide $\mathbf{1 5}$ with $\mathbf{5 d}$. On the other hand, the presence of $\mathbf{2 4}$ could be explained with a detosylation of benzoazepine 21d probably favoured by the presence of a strong electronwithdrawing group $(\mathrm{CN})$ and by the formation of an intramolecular hydrogen bond (Figure 6).

Table 3. Cyclocarbonylative Sonogashira reactions of amide 15 with iodoarenes 5 .

\begin{tabular}{|c|c|c|c|c|c|}
\hline Entry $^{[a]}$ & 5 & $\mathrm{Ar}$ & 21 & $\begin{array}{c}\text { Selectivity }(\%)^{[b]} \\
(s-\text { trans} \text { s-cis })\end{array}$ & Yield $^{[c]}$ \\
\hline 1 & a & $\mathrm{Ph}$ & a & $100(40 / 60)^{[\mathrm{d}]}$ & 52 \\
\hline 2 & b & 4- $\mathrm{MeOC}_{6} \mathrm{H}_{4}$ & b & $91^{[\mathrm{el}]}(50 / 50)$ & 65 \\
\hline 3 & $f$ & 2- $\mathrm{MeOC}_{6} \mathrm{H}_{4}$ & $f$ & $100(65 / 35)^{[d]}$ & 46 \\
\hline 4 & c & $4-\mathrm{ClC}_{6} \mathrm{H}_{4}$ & c & $100(64 / 36)$ & 61 \\
\hline 5 & d & 4- $\mathrm{NCC}_{6} \mathrm{H}_{4}$ & d & $68^{[f]}(78 / 22)$ & 63 \\
\hline
\end{tabular}

[a] Reactions were performed with $15(0.5 \mathrm{mmol}), 5 \mathrm{a}(0.6 \mathrm{mmol})$, in $\mathrm{Et}_{3} \mathrm{~N}(1.5$ $\mathrm{mL})$ and toluene $(1 \mathrm{~mL})$, under $\mathrm{CO}(2.0 \mathrm{MPa})$, 6h. [b] Selectivity was estimated by ${ }^{1} \mathrm{H}-\mathrm{NMR}$ spectroscopy of crude products; conformers ratio is reported in parentheses. [c] Remainder of product is 4-methyl- $\mathrm{N}$-(2-(3-oxo-3phenylprop-1-yn-1-I)phenethyl)benzenesulfonamide (20). [d] After purification the conformer ratio resulted 60/40 (s-trans/s-cis). [e] Reaction carried out under CO 4.0 MPa pressure. [f] Remainder of product is $\mathrm{N}-(2-((4-$ cyanophenyl)ethynyl)phenethyl)-4-methylbenzenesulfonamide (23) $(21 \%)$ and (2,3-dihydro-1 $\mathrm{H}$-benzo[d]azepin-4-yl)(phenyl)methanone (24) (11\%).

Indeed, when the same reaction was performed for a longer reaction time, (24hs, Scheme 11 ), the selectivity towards 23 did not change significantly ( $20 \%$ vs. $21 \%$ Table 3 , entry 5 ), while the amount of $21 \mathrm{~d}$ lowered from $68 \%$ to $38 \%$ with the corresponding increase of $\mathbf{2 4}$ (42\% vs. $11 \%$ Table 3, entry 5). 


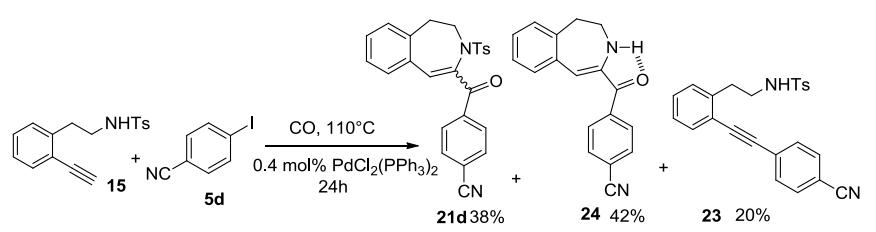

Scheme 11. Synthesis of 4-(3-tosyl-2,3-dihydro-1H-benzo[d]azepine-4carbonyl)benzonitrile (21d) and its in situ detosylation to $\mathbf{2 4}$.

Finally a cyclocarbonylative Sonogashira reaction of sulfonamide 15 was carried out in the presence of 1-iodo-4nitrobenzene $(\mathbf{5 g})$. As depicted in Scheme 12, in this case (4aminophenyl)(3-tosyl-2,3-dihydro-1 $H$-benzo[d]azepin-4-

$\mathrm{yl})$ methanone $(\mathbf{2 1} \mathbf{g})$ was obtained as the sole product $(30 \%$, purified compound). This result is in agreement with our previous reactions of benzyl and homobenzyl alcohols and $\mathbf{5} \mathbf{g}^{[7]}$. Indeed, in all these tests the quantitative reduction of $\mathrm{NO}_{2}$ to $\mathrm{NH}_{2}$ was detected.

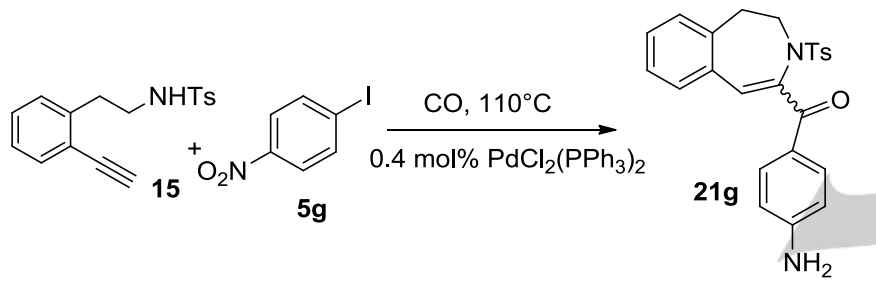

Scheme 12. Sonogashira cyclocarbonylative reaction of $\mathrm{N}-(2$ ethynylphenethyl)-4-methylbenzenesulfonamide (15) and 1-iodo-4nitrobenzene $(\mathbf{5 g})$.

\section{Conclusions}

We have developed a new approach for the synthesis of alkylideneisoindolines and dihydrobenzoazepine through a Pdcatalyzed copper-free cyclocarbonylative coupling reaction. This sequence involves a carbonylative Sonogashira reaction ${ }^{[11]}$ between a suitable amide and a iodoarene followed by a spontaneous cyclization process. In particular, when $\mathrm{N}-(2-$ ethynylbenzyl)-4-methylbenzenesulfonamide was employed, the reaction took place with complete chemo- and stereoselectivity towards the exclusive formation of the five-membered isoindoline derivatives with $E$ configuration. On the other hand, the Sonogashira cyclocarbonylative reaction of $\mathrm{N}$-(2ethynylphenethyl)-4-methylbenzenesulfonamide with iodoarenes generated dihydrobenzoazepines instead of the expected tetrahydroisoquinolines. In this case a fine tuning of the reaction conditions $\left(110^{\circ} \mathrm{C}, 0.4 \mathrm{~mol} \% \mathrm{PdCl}_{2}\left(\mathrm{PPh}_{3}\right)_{2}, 6 \mathrm{~h}\right)$ and purification technique was necessary to achieve the seven member rings with good yields. Moreover, the chemoselectivity of the reaction depended on the features of the substituent on the benzene ring. Indeed if the reaction was carried out with iodoarenes characterized by an electron donating group such as OMe, the benzoazepine was generated with almost complete chemoselectivity, while in the presence of electron withdrawing groups $\left(\mathrm{CN}, \mathrm{NO}_{2}\right)$, more complex results were obtained, i.e. detosylation and reduction occurred.

\section{Experimental Section}

General information. All chemicals were from commercial sources and used as received. Solvents were purified by conventional methods, distilled and stored under argon. ${ }^{1} \mathrm{H}-\mathrm{NMR}(600 \mathrm{MHz})$ and ${ }^{13} \mathrm{C}-\mathrm{NMR}(150$ $\mathrm{MHz}$ ) spectra were recorded in $\mathrm{CDCl}_{3}$ or DMSO- $d_{6}$ solution with a Varian INOVA - 600 spectrometer, with $\mathrm{Me}_{4} \mathrm{Si}$ or $\mathrm{CHCl}_{3}$ as internal standard; $\delta$ values are given in parts per million (ppm) and coupling constants $(\mathrm{J})$ in hertz. Mass spectra were obtained with a Perkin-Elmer Q-Mass 910 connected to a Perkin-Elmer 8500 gas chromatograph or with an Applied Biosystems- MDS Sciex API 4000 triple quadrupole mass spectrometer (Concord, Ont., Canada), equipped with a Turbo-V ion-spray (TIS) source. In the second case, the operative parameters were as follows: ion-spray voltage (IS), $5.0 \mathrm{kV}$; gas source 1 (GS1), 25; gas source 2(GS2), 25; turbo temperature (TEM), $0^{\circ} \mathrm{C}$; entrance potential (EP), $10 \mathrm{~V}$; declustering potential (DP), $20 \mathrm{~V}$; scan range, 300-1500 m/z. MS-MS spectra were produced by collision-induced dissociation (CID) of selected precursor ions in a LINAC collision cell (Q2) and mass-analyzed in the second mass filter (Q3). Column chromatography was performed on silica gel 60 (70-230 mesh) or neutral alumina. All products were identified and characterized by spectroscopic and spectrometric data.

General procedure for the cyclocarbonylative Sonogashira reactions. A Pyrex Schlenk tube under $\mathrm{CO}$ atmosphere was charged with ethynylamide (0.5-1.0 mmol), iodoarene (0.6-1.2 $\mathrm{mmol}^{\text {) }} \mathrm{Et}_{3} \mathrm{~N}$ (1.5-3 $\mathrm{mL}$ ) and toluene (1-2 $\mathrm{mL})$. This solution was introduced by a steel siphon into a $25 \mathrm{~mL}$ stainless steel autoclave, fitted with a Teflon inner crucible and a stirring bar, previously carried with $\mathrm{PdCl}_{2}\left(\mathrm{PPh}_{3}\right)_{2}(0.2-0.4 \mathrm{~mol} \%)$ and placed under vacuum ( 0.1 Torr). The reactor was pressurized with CO (2.0 MPa) and the mixture was stirred for 2-6hs at a selected temperature $\left(100-110^{\circ} \mathrm{C}\right)$. After removal of excess $\mathrm{CO}$ (fume hood), the reaction mixture was diluted with $\mathrm{CH}_{2} \mathrm{Cl}_{2}$, washed with brine, dried over anhydrous $\mathrm{Na}_{2} \mathrm{SO}_{4}$ and the solvent was removed under vacuum. The reagent conversion and the product composition were determined by ${ }^{1} \mathrm{H}$ NMR spectroscopic analysis. All crude products were purified through column chromatography on silica gel or neutral alumina and characterized with ${ }^{1} \mathrm{H}$-NMR, ${ }^{13} \mathrm{C}-\mathrm{NMR}$ and LC-MS techniques.

(E)-tert-butyl 1-(2-oxo-2-phenylethylidene)isoindoline-2-carboxylate (12aa). Following the general procedure, $\mathrm{PdCl}_{2}\left(\mathrm{PPh}_{3}\right)_{2}(0.8 \mathrm{mg}, 0.0011$ $\mathrm{mmol}$ ), tert-butyl 2-ethynylbenzylcarbamate $(8 \mathrm{a})(151 \mathrm{mg}, 0.50 \mathrm{mmol}$ ) and iodobenzene (5a) $(0.07 \mathrm{~mL}, 0.63 \mathrm{mmol})$ were mixed in $\mathrm{Et}_{3} \mathrm{~N}(1.5 \mathrm{~mL})$ and toluene $(1 \mathrm{~mL})$. The mixture was stirred for $4 \mathrm{~h}$ at $100^{\circ} \mathrm{C}$. The crude product was purified through column chromatography $\left(\mathrm{SiO}_{2}, n\right.$ hexane/AcOEt 9:1); $28 \mathrm{mg}$ of 12aa (yield 14\%) and $100 \mathrm{mg}$ of the side product tert-butyl 2-(3-oxo-3-phenylprop-1-yn-1-yl)benzylcarbamate (13) (yield $49 \%$ ) were obtained.

12aa: ${ }^{1} \mathrm{H}-\mathrm{NMR}\left(\mathrm{CDCl}_{3}\right), \delta(\mathrm{ppm}): 1.61(9 \mathrm{H}, \mathrm{s}), 4.89(2 \mathrm{H}, \mathrm{s}), 7.35-7.40(2 \mathrm{H}$, m), $7.47(3 \mathrm{H}, \mathrm{t}, \mathrm{J}=7.4 \mathrm{~Hz}), 7.50-7.54(1 \mathrm{H}, \mathrm{m}), 8.09(2 \mathrm{H}, \mathrm{d}, \mathrm{J}=7.4 \mathrm{~Hz})$, $8.22(1 \mathrm{H}, \mathrm{s}), 9.08(1 \mathrm{H}, \mathrm{d}, \mathrm{J}=8.1 \mathrm{~Hz})$.

${ }^{13} \mathrm{C}-\mathrm{NMR}\left(\mathrm{CDCl}_{3}\right)$, $\delta(\mathrm{ppm}): 28.29(3 \mathrm{C}), 54.07,82.46,103.70,121.54$, $127.81,127.99,128.31$ (2C), 128.34 (2C), 131.16, 131.88, 133.77, 138.56, 140.43, 152.00, 153.10, 190.51.

LC-MS APCl (+) $[\mathrm{M}+\mathrm{H}]^{+}: 336.1$. 
13: ${ }^{1} \mathrm{H}-\mathrm{NMR}\left(\mathrm{CDCl}_{3}\right), \delta(\mathrm{ppm}): 1.46(9 \mathrm{H}, \mathrm{s}), 4.60(2 \mathrm{H}, \mathrm{d}, \mathrm{J}=5.1 \mathrm{~Hz}), 5.14$ $(1 \mathrm{H}, \mathrm{bs}), 7.32-7.35(1 \mathrm{H}, \mathrm{m}), 7.46-7.48(2 \mathrm{H}, \mathrm{m}), 7.54(2 \mathrm{H}, \mathrm{t}, \mathrm{J}=7.6 \mathrm{~Hz})$, $7.65(1 \mathrm{H}, \mathrm{t}, \mathrm{J}=7.3 \mathrm{~Hz}), 7.69(1 \mathrm{H}, \mathrm{d}, \mathrm{J}=7.6 \mathrm{~Hz}), 8.22(2 \mathrm{H}, \mathrm{d}, \mathrm{J}=7.6 \mathrm{~Hz})$. ${ }^{13} \mathrm{C}-\mathrm{NMR}\left(\mathrm{CDCl}_{3}\right), \delta(\mathrm{ppm}): 28.35$ (3C), 43.17, 79.66, 90.51, 91.29, $118.87,127.45,128.15,128.70$ (2C), 129.52 (2C), 131.15, 133.87, $134.18,136.77,142.64,155.81,177.77$. LC-MS APCl $(+)[\mathrm{M}+\mathrm{H}]^{+}: 336.1$. (E)-1-phenyl-2-(2-tosylisoindolin-1-ylidene)ethanone (12ab) $\left(100^{\circ} \mathrm{C}\right)$ Following the general procedure, $\mathrm{PdCl}_{2}\left(\mathrm{PPh}_{3}\right)_{2}(1.4 \mathrm{mg}, 0.0020 \mathrm{mmol})$, $\mathrm{N}$-tosyl-2-(ethynyl)benzylamine $\quad(\mathbf{8 b}) \quad(289 \mathrm{mg}, \quad 1.0 \mathrm{mmol})$ and iodobenzene $(5 \mathbf{a})(0.15 \mathrm{~mL}, 1.3 \mathrm{mmol})$ were mixed in $\mathrm{Et}_{3} \mathrm{~N}(3 \mathrm{~mL})$ and toluene $(2 \mathrm{~mL})$. The mixture was stirred for $24 \mathrm{~h}$ at $100^{\circ} \mathrm{C}$. The crude product was purified through column chromatography $\left(\mathrm{SiO}_{2}, n-\right.$ hexane/AcOEt 4:1), obtaining $280 \mathrm{mg}$ (yield $72 \%$ ) of 12ab. ${ }^{1} \mathrm{H}-\mathrm{NMR}$ $\left(\mathrm{CDCl}_{3}\right), \delta(\mathrm{ppm}): 2.32(3 \mathrm{H}, \mathrm{s}), 5.07(2 \mathrm{H}, \mathrm{s}) ; 7.24(2 \mathrm{H}, \mathrm{d}, \mathrm{J}=8.4 \mathrm{~Hz})$, 7.30-735 (2H, m); 7.41-7.53 (5H, m); $7.78(2 \mathrm{H}, \mathrm{d}, \mathrm{J}=8.4 \mathrm{~Hz}) ; 7.99(2 \mathrm{H}$, $\mathrm{d}, \mathrm{J}=6.9 \mathrm{~Hz}) ; 8.99(1 \mathrm{H}, \mathrm{d}, \mathrm{J}=8.7 \mathrm{~Hz}) .{ }^{13} \mathrm{C}-\mathrm{NMR}\left(\mathrm{CDCl}_{3}\right), \delta(\mathrm{ppm})$ : $21.48,55.35,101.88,121.78,127.42$ (2C), 128.19 (4C), $128.42(2 \mathrm{C})$, 129.97 (2C), 131.62, 132.18, 132.94, 134.65, 138.21, 139.88, 145.00, 152.48, 188.89.LC-MS APCI $(+)[\mathrm{M}+\mathrm{H}]^{+}: 390.2$.

\section{(E)-1-phenyl-2-(2-tosylisoindolin-1-ylidene)ethanone (12ab) $\left(30^{\circ} \mathrm{C}\right)$}

Following the general procedure, $\mathrm{PdCl}_{2}\left(\mathrm{PPh}_{3}\right)_{2}(0.7 \mathrm{mg}, 0.0010 \mathrm{mmol})$, $\mathrm{N}$-tosyl-2-(ethynyl)benzylamine $\quad(\mathbf{8 b}) \quad(142 \mathrm{mg}, \quad 0.50 \quad \mathrm{mmol})$ and iodobenzene $(5 \mathbf{a})(0.07 \mathrm{~mL}, 0.62 \mathrm{mmol})$ were mixed in $\mathrm{Et}_{3} \mathrm{~N}(1.5 \mathrm{~mL})$ and toluene $(1 \mathrm{~mL})$. The mixture was stirred for $4 \mathrm{~h}$ at $30^{\circ} \mathrm{C}$. The crude product was purified through column chromatography $\left(\mathrm{SiO}_{2}, n\right.$ hexane/AcOEt 4:1), obtaining $19 \mathrm{mg}$ (yield 10\%) of 12ab and $162 \mathrm{mg}$ (yield 90\%) of the side product 4-methyl- $N$-(2-(phenylethynyl) benzyl)benzenesulfonamide (14): ${ }^{1} \mathrm{H}-\mathrm{NMR}\left(\mathrm{CDCl}_{3}\right), \delta(\mathrm{ppm}): 2.29(3 \mathrm{H}$, s), $4.28(2 \mathrm{H}, \mathrm{s}), 4.94(1 \mathrm{H}, \mathrm{bs}), 7.09-7.12(2 \mathrm{H}, \mathrm{m}), 7.14-7.21(3 \mathrm{H}, \mathrm{m})$, 7.27-7.39 $(6 \mathrm{H}, \mathrm{m}), 7.63(2 \mathrm{H}, \mathrm{d}, \mathrm{J}=8.4 \mathrm{~Hz}) .{ }^{13} \mathrm{C}-\mathrm{NMR}\left(\mathrm{CDCl}_{3}\right)$, $\delta(\mathrm{ppm})$ : $21.48,46.25,86.47,94.40,122.24,122.51,127.10$ (2C), 127.83, 128.39 (2C), 128.69 (2C), 128.79, 129.55 (2C), 131.52 (2C), 132.27, 136.87, $137.73,143.25$.

\section{(E)-1-(4-methoxyphenyl)-2-(2-tosylisoindolin-1-ylidene)ethanone}

(12bb). Following the general procedure, $\mathrm{PdCl}_{2}\left(\mathrm{PPh}_{3}\right)_{2}(0.7 \mathrm{mg}, 0.0010$ $\mathrm{mmol}), \mathrm{N}$-tosyl-2-(ethynyl)benzylamine (8b) $(142 \mathrm{mg}, 0.50 \mathrm{mmol})$ and 4 iodoanisole $(5 \mathbf{b})\left(147 \mathrm{mg}, 0.63 \mathrm{mmol}\right.$ ) were mixed in $\mathrm{Et}_{3} \mathrm{~N}(1.5 \mathrm{~mL})$ and toluene $(1 \mathrm{~mL})$. The mixture was stirred for $4 \mathrm{~h}$ at $100^{\circ} \mathrm{C}$. The crude product was purified through column chromatography $\left(\mathrm{SiO}_{2}, n-\right.$ hexane/AcOEt 4:1), obtaining $150 \mathrm{mg}$ (yield $72 \%$ ) of 12bb: ${ }^{1} \mathrm{H}-\mathrm{NMR}$ $\left(\mathrm{CDCl}_{3}\right), \delta(\mathrm{ppm}): 2.26(3 \mathrm{H}, \mathrm{s}), 3.77(3 \mathrm{H}, \mathrm{s}), 4.97(2 \mathrm{H}, \mathrm{s}), 6.86(2 \mathrm{H}, \mathrm{d}, \mathrm{J}=$ $9 \mathrm{~Hz}), 7.17(2 \mathrm{H}, \mathrm{d}, \mathrm{J}=8.2 \mathrm{~Hz}), 7.21-7.26(2 \mathrm{H}, \mathrm{m}), 7.32-7.37(2 \mathrm{H}, \mathrm{m})$, $7.69(2 \mathrm{H}, \mathrm{d}, \mathrm{J}=8.2 \mathrm{~Hz}) ; 7.90(2 \mathrm{H}, \mathrm{d}, \mathrm{J}=9.0 \mathrm{~Hz}), 8.80(1 \mathrm{H}, \mathrm{d}, \mathrm{J}=8.7 \mathrm{~Hz})$. ${ }^{13} \mathrm{C}-\mathrm{NMR}\left(\mathrm{CDCl}_{3}\right), \delta(\mathrm{ppm}): 21.44,55.22,55.36,102.06,113.58(2 \mathrm{C})$, $121.75,127.34$ (2C), 127.98, 128.06, 129.91 (2C), 130.41 (2C), 131.35, 132.56, 132.87, 134.52, 138.01, 144.88, 151.51 (2C), 162.92, 187.73. LC-MS APCl (+) [M+H] : 420.2 .

\section{(E)-1-(4-chlorophenyl)-2-(2-tosylisoindolin-1-ylidene)ethanone}

(12cb). Following the general procedure, $\mathrm{PdCl}_{2}\left(\mathrm{PPh}_{3}\right)_{2}(0.7 \mathrm{mg}, 0.0010$ $\mathrm{mmol}$ ), $\mathrm{N}$-tosyl-2-(ethynyl)benzylamine (8b) (142 $\mathrm{mg}, 0.50 \mathrm{mmol}$ ) and 1 chloro-4-iodobenzene $(\mathbf{5 c})(149 \mathrm{mg}, 0.62 \mathrm{mmol})$ were mixed in $\mathrm{Et}_{3} \mathrm{~N}(1.5$ $\mathrm{mL}$ ) and toluene $(1 \mathrm{~mL})$. The mixture was stirred for $4 \mathrm{~h}$ at $100^{\circ} \mathrm{C}$. The crude product was purified through column chromatography $\left(\mathrm{SiO}_{2}, n-\right.$ hexane/AcOEt 4:1), obtaining $138 \mathrm{mg}$ (yield $65 \%$ ) of $12 \mathrm{cb}$ : ${ }^{1} \mathrm{H}-\mathrm{NMR}$ $\left(\mathrm{CDCl}_{3}\right), \delta(\mathrm{ppm}): 2.34(3 \mathrm{H}, \mathrm{s}), 5.06(2 \mathrm{H}, \mathrm{s}), 7.25(2 \mathrm{H}, \mathrm{d}, \mathrm{J}=8.1 \mathrm{~Hz})$, 7.33-7.36 (3H, m), $7.41(2 \mathrm{H}, \mathrm{d}, \mathrm{J}=8.4 \mathrm{~Hz}), 7.43-7.46(1 \mathrm{H}, \mathrm{m}), 7.74(2 \mathrm{H}$, $\mathrm{d}, \mathrm{J}=8.1 \mathrm{~Hz}), 7.88(2 \mathrm{H}, \mathrm{d}, \mathrm{J}=8.4 \mathrm{~Hz}), 8.94(1 \mathrm{H}, \mathrm{d}, \mathrm{J}=7.8 \mathrm{~Hz}) .{ }^{13} \mathrm{C}-\mathrm{NMR}$
$\left(\mathrm{CDCl}_{3}\right), \delta(\mathrm{ppm}): 21.58,55.47,101.15,121.87,127.45(2 \mathrm{C}), 128.29$, 128.32, 128.74 (2C), 129.66 (2C), 130.08 (2C), 131.89, 132.89, 134.53, $138.31,138.33,138.56,145.23,153.16,187.56$. LC-MS APCl (+) $[\mathrm{M}+\mathrm{H}]^{+}: 420.2$.

(E)-4-(2-(2-tosylisoindolin-1-ylidene)acetyl)benzonitrile

(12db). Following the general procedure, $\mathrm{PdCl}_{2}\left(\mathrm{PPh}_{3}\right)_{2}(0.7 \mathrm{mg}, 0.0010 \mathrm{mmol})$, $\mathrm{N}$-tosyl-2-(ethynyl)benzylamine (8b) $(142 \mathrm{mg}, 0.50 \mathrm{mmol})$ and 4 iodobenzonitrile $(\mathbf{5 d})(144 \mathrm{mg}, 0.63 \mathrm{mmol})$ were mixed in $\mathrm{Et}_{3} \mathrm{~N}(1.5 \mathrm{~mL})$ and toluene $(1 \mathrm{~mL})$. The mixture was stirred for $4 \mathrm{~h}$ at $100^{\circ} \mathrm{C}$. The crude product was purified through column chromatography $\left(\mathrm{SiO}_{2}, n-\right.$ hexane/AcOEt 4:1), obtaining $124 \mathrm{mg}$ (yield $60 \%$ ) of $12 \mathrm{db}:{ }^{1} \mathrm{H}-\mathrm{NMR}$ $\left(\mathrm{CDCl}_{3}\right), \delta(\mathrm{ppm}): 2.40(3 \mathrm{H}, \mathrm{s}), 5.13(2 \mathrm{H}, \mathrm{s}), 7.23(2 \mathrm{H}, \mathrm{d}, \mathrm{J}=8.4 \mathrm{~Hz})$, 7.32-7.35 (2H, m), 7.45-7.48 (1H, m), 7.71 (4H, dd, J = 8.4, 1.5 Hz), 7.98 $(2 \mathrm{H}, \mathrm{d}, \mathrm{J}=8.4 \mathrm{~Hz}), 9.01(1 \mathrm{H}, \mathrm{d}, \mathrm{J}=8.4 \mathrm{~Hz}) .{ }^{13} \mathrm{C}-\mathrm{NMR}\left(\mathrm{CDCl}_{3}\right), \delta(\mathrm{ppm})$ : 21.59, 55.62, 100.29, 115.27, 118.22, 121.95, 127.43 (2C), 128.42, $128.46,128.56(2 \mathrm{C}), 130.14(2 \mathrm{C}), 132.32,132.36(2 \mathrm{C}), 132.80,134.44$, $138.58,143.57,145.44,154.61,186.79$.

\section{(E)-1-(naphthalen-2-yl)-2-(2-tosylisoindolin-1-ylidene)ethanone}

(12eb). Following the general procedure, $\mathrm{PdCl}_{2}\left(\mathrm{PPh}_{3}\right)_{2}(0.7 \mathrm{mg}, 0.0010$ $\mathrm{mmol}$ ), $\mathrm{N}$-tosyl-2-(ethynyl)benzylamine $(\mathbf{8 b})(142 \mathrm{mg}, 0.50 \mathrm{mmol})$ and 2iodonaphthalene $(5 \mathbf{e})(0.09 \mathrm{~mL}, 0.62 \mathrm{mmol})$ were mixed in $\mathrm{Et}_{3} \mathrm{~N}(1.5 \mathrm{~mL})$ and toluene $(1 \mathrm{~mL})$. The mixture was stirred for $4 \mathrm{~h}$ at $100^{\circ} \mathrm{C}$. The crude product was purified through column chromatography $\left(\mathrm{SiO}_{2}, n\right.$ hexane/AcOEt 7:3), obtaining $149 \mathrm{mg}$ (yield $68 \%$ ) of 12eb: ${ }^{1} \mathrm{H}-\mathrm{NMR}$ $\left(\mathrm{CDCl}_{3}\right), \delta(\mathrm{ppm}): 2.41(3 \mathrm{H}, \mathrm{s}), 5.16(2 \mathrm{H}, \mathrm{s}), 7.19(1 \mathrm{H}, \mathrm{s}), 7.26(2 \mathrm{H}, \mathrm{d}, \mathrm{J}=$ $6.6 \mathrm{~Hz}), 7.42(2 \mathrm{H}, \mathrm{t}, \mathrm{J}=8.5 \mathrm{~Hz}), 7.48-7.56(4 \mathrm{H}, \mathrm{m}), 7.73(2 \mathrm{H}, \mathrm{d}, \mathrm{J}=7.8$ $\mathrm{Hz}), 7.90-7.92(1 \mathrm{H}, \mathrm{m}), 7.98(1 \mathrm{H}, \mathrm{d}, \mathrm{J}=8.4 \mathrm{~Hz}), 8.50-8.51(1 \mathrm{H}, \mathrm{m}), 9.15$ $(1 \mathrm{H}, \mathrm{d}, \mathrm{J}=7.8 \mathrm{~Hz}) \cdot{ }^{13} \mathrm{C}-\mathrm{NMR}\left(\mathrm{CDCl}_{3}\right), \delta(\mathrm{ppm}): 21.58,21.61,55.55$, 105.57, 105.62, 121.87, 124.61, 125.77, 126.18, 127.22, 127.63, 128.37 (2C), 128.41, 129.99, 130.03, 130.33, 131.57, 131.90, 133.04, 133.89, $134.52,138.35,139.20,145.10,152.47,192.57$. LC-MS APCI (+) $[\mathrm{M}+\mathrm{H}]^{+}: 440.2$.

\section{(E)-1-(2-methoxyphenyl)-2-(2-tosylisoindolin-1-ylidene)ethanone}

(12fb). Following the general procedure, $\mathrm{PdCl}_{2}\left(\mathrm{PPh}_{3}\right)_{2}(0.7 \mathrm{mg}, 0.0010$ $\mathrm{mmol}), \mathrm{N}$-tosyl-2-(ethynyl)benzylamine (8b) $(142 \mathrm{mg}, 0.50 \mathrm{mmol})$ and 2iodoanisole $(5 \mathrm{f})(0.08 \mathrm{~mL}, 0.62 \mathrm{mmol})$ were mixed in $\mathrm{Et}_{3} \mathrm{~N}(1.5 \mathrm{~mL})$ and toluene $(1 \mathrm{~mL})$. The mixture was stirred for $4 \mathrm{~h}$ at $100^{\circ} \mathrm{C}$. The crude product was purified through column chromatography $\left(\mathrm{SiO}_{2}, n\right.$ hexane/AcOEt 7:3), obtaining $115 \mathrm{mg}$ (yield $55 \%$ ) of $12 \mathrm{fb}:{ }^{1} \mathrm{H}-\mathrm{NMR}$ $\left(\mathrm{CDCl}_{3}\right), \delta(\mathrm{ppm}): 2.38(3 \mathrm{H}, \mathrm{s}), 3.97(3 \mathrm{H}, \mathrm{s}), 5.06(2 \mathrm{H}, \mathrm{s}), 7.02-7.04(2 \mathrm{H}$, m), 7.26-7.47 (6H, m), $7.62(1 \mathrm{H}, \mathrm{s}), 7.71-7.73(1 \mathrm{H}, \mathrm{m}), 7.81(2 \mathrm{H}, \mathrm{d}, \mathrm{J}=$ $7.2 \mathrm{~Hz}), 9.16(1 \mathrm{H}, \mathrm{d}, \mathrm{J}=7.8 \mathrm{~Hz}) .{ }^{13} \mathrm{C}-\mathrm{NMR}\left(\mathrm{CDCl}_{3}\right), \delta(\mathrm{ppm}): 21.56$, 29.68, 55.27, 55.82, 106.76, 111.77, 120.57, 121.69, 127.47, 128.19, $128.36,129.90(2 \mathrm{C}), 130.53,131.54,131.89,132.69,133.47,134.67$ $138.16,144.85,152.17,158.05,189.70$. LC-MS APCI (+) [M+H] ${ }^{+}: 420.2$.

Phenyl(3-tosyl-2,3-dihydro-1H-benzo[d]azepin-4-yl)methanone (21a) $\left(100^{\circ} \mathrm{C}\right)$. Following the general procedure, $\mathrm{PdCl}_{2}\left(\mathrm{PPh}_{3}\right)_{2}(0.7 \mathrm{mg}, 0.0010$ mmol), $\quad N$-tosyl-2-(2-(ethynyl)phenyl)ethanamine (15) $(150 \mathrm{mg}, 0.50$ $\mathrm{mmol})$ and iodobenzene $(5 \mathrm{a})(0.07 \mathrm{~mL}, 0.62 \mathrm{mmol})$ were mixed in $\mathrm{Et}_{3} \mathrm{~N}$ $(1.5 \mathrm{~mL})$ and toluene $(1.0 \mathrm{~mL})$. The mixture was stirred for $4 \mathrm{~h}$ at $100^{\circ} \mathrm{C}$ The crude product was purified through column chromatography $\left(\mathrm{SiO}_{2}\right.$, $\mathrm{CHCl}_{3} / \mathrm{EtOH}$ 99:1), obtaining $52 \mathrm{mg}$ (yield 26\%) of 21a as two conformational isomers, $s$-trans and $s$-cis, in the molar ratio $60 / 40$, and 6 $\mathrm{mg}$ (yield $3 \%$ ) of the side product 4-methyl- $\mathrm{N}$-(2-(3-oxo-3-phenylprop-1yn-1-yl)phenethyl) benzenesulfonamide (20). 21a: ${ }^{1} \mathrm{H}-\mathrm{NMR}\left(\mathrm{CDCl}_{3}\right), \delta$ (ppm): $2.30\left(\mathrm{CH}_{3}, \mathrm{~s}, 1.8 \mathrm{H}\right), 2.35\left(\mathrm{CH}_{3}, \mathrm{~s}, 1.2 \mathrm{H}\right), 2.58\left(\mathrm{CH}_{2}, \mathrm{t}, \mathrm{J}=6.0 \mathrm{~Hz}\right.$, $1.2 \mathrm{H}), 2.87\left(\mathrm{CH}_{2}, \mathrm{t}, \mathrm{J}=6.0 \mathrm{~Hz}, 0.8 \mathrm{H}\right), 3.71\left(\mathrm{CH}_{2}, \mathrm{t}, \mathrm{J}=6.0 \mathrm{~Hz}, 1.2 \mathrm{H}\right)$, 
$3.74\left(\mathrm{CH}_{2}, \mathrm{t}, \mathrm{J}=6.0 \mathrm{~Hz}, 0.8 \mathrm{H}\right), 6.93-6.95(\mathrm{Ar}, \mathrm{m}, 0.6 \mathrm{H}), 6.96-6.99$ (Ar, m, $0.8 \mathrm{H}), 7.05-7.08(\mathrm{Ar}, \mathrm{m}, 1.6 \mathrm{H}), 7.11(=\mathrm{CH}, \mathrm{s}, 0.6 \mathrm{H}), 7.17-7.26(\mathrm{Ar}, \mathrm{m}$, $3 \mathrm{H}), 7.35(=\mathrm{CH}, \mathrm{s}, 0.4 \mathrm{H}), 7.43-7.49(\mathrm{Ar}, \mathrm{m}, 2 \mathrm{H})$, 7.53-7.57 (Ar, m, $2 \mathrm{H})$, 7.68 (Ar, d, J = 8.4 Hz, 0.8H), 7.73-7.75 (Ar, m, 0.6H), 7.93-7.97 (Ar, m, 2H). ${ }^{13} \mathrm{C}-\mathrm{NMR}\left(\mathrm{CDCl}_{3}\right), \delta$ (ppm): (21.37, 21.42), (26.10, 28.68), (44.41, 45.59), (111.79, 119.63), (124.33, 125.88), (126.41, 126.85), (127.31, 127.35) (2C), (128.04, 128.49) (2C), 128.61 (2C), (129.06, 129.10), $(129.28,129.55)(2 \mathrm{C}),(129.70,129.75),(130.59,130.89),(132.19$, 132.92), (134.87, 135.17), (136.34, 136.61), (138.15, 138.71), (140.98, 143.68), (144.11, 144.13), (191.41, 193.42). LC-MS APCI $(+)[\mathrm{M}+\mathrm{H}]^{+}$: 404.6.

20: ${ }^{1} \mathrm{H}-\mathrm{NMR}\left(\mathrm{CDCl}_{3}\right), \delta$ (ppm): $2.31(3 \mathrm{H}, \mathrm{s}), 3.10(2 \mathrm{H}, \mathrm{t}, \mathrm{J}=7.1 \mathrm{~Hz}), 3.28-$ $3.31(2 \mathrm{H}, \mathrm{m}), 5.51(1 \mathrm{H}, \mathrm{t}, \mathrm{J}=6.0 \mathrm{~Hz}), 7.28-7.30(1 \mathrm{H}, \mathrm{m}), 7.32-7.35(2 \mathrm{H}$, m), 7.50-7.53 (2H, m), $7.59(2 \mathrm{H}, \mathrm{d}, \mathrm{J}=7.6 \mathrm{~Hz}), 7.66(1 \mathrm{H}, \mathrm{d}, \mathrm{J}=7.6 \mathrm{~Hz})$. ${ }^{13} \mathrm{C}-\mathrm{NMR}\left(\mathrm{CDCl}_{3}\right), \delta(\mathrm{ppm}): 21.38,34.76,43.46,90.77,91.18,126.94$, 127.38, 128.12 (4C), 128.93 (4C), 130.16, 131.06, 133.98, 134.19, 137.32, 137.67, 142.06, 143.08, 177.69.

Phenyl(3-tosyl-2,3-dihydro-1H-benzo[d]azepin-4-yl)methanone (21a) $\left(50^{\circ} \mathrm{C}\right)$. Following the general procedure, $\mathrm{PdCl}_{2}\left(\mathrm{PPh}_{3}\right)_{2}(17.5 \mathrm{mg}, 0.025$ $\mathrm{mmol}), \quad \mathrm{N}$-tosyl-2-(2-(ethynyl)phenyl)ethanamine (15) $(150 \mathrm{mg}, 0.50$ $\mathrm{mmol})$ and iodobenzene $(5 \mathrm{a})(0.07 \mathrm{~mL}, 0.62 \mathrm{mmol})$ were mixed in $\mathrm{Et}_{3} \mathrm{~N}$ $(1.5 \mathrm{~mL})$ and toluene $(1.0 \mathrm{~mL})$. The mixture was stirred for $24 \mathrm{~h}$ at $50^{\circ} \mathrm{C}$. The crude product was purified through column chromatography $\left(\mathrm{SiO}_{2}\right.$, $\mathrm{CH}_{2} \mathrm{Cl}_{2} /$ acetone $49: 1$ ), obtaining $58 \mathrm{mg}$ (yield $29 \%$ ) of 21a as two conformational isomers, $s$-trans and $s$-cis, in the molar ratio $67 / 33,16 \mathrm{mg}$ (yield $8 \%$ of $\quad 4$-methyl- $N$-(2-(3-oxo-3-phenylprop-1-yn-1yl)phenethyl)benzenesulfonamide (20) and $12 \mathrm{mg}$ (yield $4 \%$ ) of the side product $N, N^{\prime}$-((buta-1,3-diyne-1,4-diylbis(2,1-phenylene)) bis(ethane-2,1diyl))bis(4-methylbenzenesulfonamide) (22): ${ }^{1} \mathrm{H}-\mathrm{NMR}\left(\mathrm{CDCl}_{3}\right), \delta(\mathrm{ppm})$ : $2.38(6 \mathrm{H}, \mathrm{s}), 3.00-3.03(4 \mathrm{H}, \mathrm{m}), 3.25-3.28(4 \mathrm{H}, \mathrm{m}), 4.84(2 \mathrm{H}, \mathrm{t}, \mathrm{J}=6.0$ $\mathrm{Hz}), 7.16(2 \mathrm{H}, \mathrm{d}, \mathrm{J}=7.8 \mathrm{~Hz}), 7.20-7.30(8 \mathrm{H}, \mathrm{m}), 7.50(2 \mathrm{H}, \mathrm{d}, \mathrm{J}=7.8 \mathrm{~Hz})$, $7.72(4 \mathrm{H}, \mathrm{d}, \mathrm{J}=7.8 \mathrm{~Hz})$. LC-MS APCl $(+)[\mathrm{M}+\mathrm{H}]^{+}: 597.4$.

\section{(4-Methoxyphenyl)(3-tosyl-2,3-dihydro-1 H-benzo[d]azepin-4-}

yl)methanone (21b). Following the general procedure, $\mathrm{PdCl}_{2}\left(\mathrm{PPh}_{3}\right)_{2}(1.4$ $\mathrm{mg}, 0.0020 \mathrm{mmol}$ ), $\mathrm{N}$-tosyl-2-(2-(ethynyl)phenyl)ethanamine (15) (150 $\mathrm{mg}, 0.50 \mathrm{mmol}$ ) and 4-iodoanisole $(5 \mathrm{~b})(145 \mathrm{mg}, 0.62 \mathrm{mmol}$ ) were mixed in $\mathrm{Et}_{3} \mathrm{~N}(1.5 \mathrm{~mL})$ and toluene $(1.0 \mathrm{~mL})$. The mixture was stirred for $6 \mathrm{~h}$ at $110^{\circ} \mathrm{C}$. The crude product was purified through column chromatography (neutral $\mathrm{Al}_{2} \mathrm{O}_{3}, n$-hexane/AcOEt 3:1), obtaining $140 \mathrm{mg}$ (yield 65\%) of 21b as two conformational isomers, $s$-trans and $s$-cis, in the molar ratio 50/50. ${ }^{1} \mathrm{H}-\mathrm{NMR}\left(\mathrm{CDCl}_{3}\right), \delta$ (ppm): $2.29\left(\mathrm{CH}_{3}, \mathrm{~s}, 1.5 \mathrm{H}\right), 2.32\left(\mathrm{CH}_{3}, \mathrm{~s}\right.$, $1.5 \mathrm{H}), 2.62\left(\mathrm{CH}_{2}, \mathrm{t}, \mathrm{J}=6.0 \mathrm{~Hz}, 1 \mathrm{H}\right), 2.84\left(\mathrm{CH}_{2}, \mathrm{t}, \mathrm{J}=6.0 \mathrm{~Hz}, 1 \mathrm{H}\right), 3.72$ $\left(\mathrm{CH}_{2}, \mathrm{t}, \mathrm{J}=6.0 \mathrm{~Hz}, 1 \mathrm{H}\right), 3.75\left(\mathrm{CH}_{2}, \mathrm{t}, \mathrm{J}=6.0 \mathrm{~Hz}, 1 \mathrm{H}\right), 3.87\left(\mathrm{CH}_{3}, \mathrm{~s}\right.$, 1.5H), $3.88\left(\mathrm{CH}_{3}, \mathrm{~s}, 1.5 \mathrm{H}\right), 6.92-6.98(\mathrm{Ar}, \mathrm{m}, 3.5 \mathrm{H}), 7.01$ (Ar, d, J = 7.2 $\mathrm{Hz}, 0.5 \mathrm{H}), 7.05-7.07$ (Ar, m, 1H), $7.09(=\mathrm{CH}, \mathrm{s}, 0.5 \mathrm{H}), 7.14-7.17$ (Ar, m, 2.5H), 7.21-7.23 (Ar, m, 0.5H), $7.29(=\mathrm{CH}, \mathrm{s}, 0.5 \mathrm{H}), 7.54$ (Ar, d, J = 7.8 $\mathrm{Hz}, 0.5 \mathrm{H}$ ), 7.65 (Ar, d, J = 7.8 Hz, 1H), 7.70-7.72 (Ar, m, 0.5H), 7.92 (Ar, d, J $=7.8 \mathrm{~Hz}, 1 \mathrm{H}), 7.98(\mathrm{Ar}, \mathrm{d}, \mathrm{J}=8.4 \mathrm{~Hz}, 1 \mathrm{H}) .{ }^{13} \mathrm{C}-\mathrm{NMR}\left(\mathrm{CDCl}_{3}\right), \delta$ (ppm): (21.42, 21.44), (26.32, 28.59), (44.63, 45.64), (55.39, 55.46), $(113.40,113.79)(2 \mathrm{C}),(119.21,120.04),(124.32,125.92),(126.50$, 126.81), (127.34, 127.50) (2C), (128.78, 129.14), (129.26, 129.53) (2C), $(130.91,131.05)(2 \mathrm{C}), 131.52,(134.88,135.30),(136.18,136.64)$, 140.21, (142.70, 143.60), 143.99, (163.05, 163.57), (190.30, 191.71). LC-MS APCl (+) [M+H] : 434.3 .

\section{(2-Methoxyphenyl)(3-tosyl-2,3-dihydro-1H-benzo[d]azepin-4-}

yl)methanone (21f). Following the general procedure, $\mathrm{PdCl}_{2}\left(\mathrm{PPh}_{3}\right)_{2}(1.4$ $\mathrm{mg}, 0.0020 \mathrm{mmol}), \mathrm{N}$-tosyl-2-(2-(ethynyl)phenyl)ethanamine (15) (150 $\mathrm{mg}, 0.50 \mathrm{mmol})$ and 2-iodoanisole $(5 \mathrm{f})(0.08 \mathrm{~mL}, 0.62 \mathrm{mmol})$ were mixed in $\mathrm{Et}_{3} \mathrm{~N}(1.5 \mathrm{~mL})$ and toluene $(1.0 \mathrm{~mL})$. The mixture was stirred for $6 \mathrm{~h}$ at $110^{\circ} \mathrm{C}$. The crude product was purified through column chromatography (neutral $\mathrm{Al}_{2} \mathrm{O}_{3}, n$-pentane/AcOEt 3:2), obtaining $99 \mathrm{mg}$ (yield $46 \%$ ) of $\mathbf{2 1 f}$ as two conformational isomers, $s$-trans and $s$-cis, in the molar ratio $60 / 40$. ${ }^{1} \mathrm{H}-\mathrm{NMR}\left(\mathrm{CDCl}_{3}\right), \delta(\mathrm{ppm}): 2.27\left(\mathrm{CH}_{3}, \mathrm{~s}, 1.8 \mathrm{H}\right), 2.33\left(\mathrm{CH}_{3}, \mathrm{~s}, 1.2 \mathrm{H}\right), 2.49$ $\left(\mathrm{CH}_{2}, \mathrm{t}, \mathrm{J}=6.0 \mathrm{~Hz}, 1.2 \mathrm{H}\right), 2.81\left(\mathrm{CH}_{2}, \mathrm{t}, \mathrm{J}=6.0 \mathrm{~Hz}, 0.8 \mathrm{H}\right), 3.65-3.68\left(\mathrm{CH}_{2}\right.$, $\mathrm{m}, 2 \mathrm{H}), 3.88\left(\mathrm{CH}_{3}, \mathrm{~s}, 1.8 \mathrm{H}\right), 3.95\left(\mathrm{CH}_{3}, \mathrm{~s}, 1.2 \mathrm{H}\right), 6.86-6.87(\mathrm{Ar}, \mathrm{m}, 0.6 \mathrm{H})$, 6.92-6.95 (Ar, m, 1H), 6.97 (Ar, d, J = 8.4 Hz, 0.8H), 7.01-7.03 (Ar, m, 1.6H), 7.06 (Ar, t, J = 7.2 Hz, 0.6H), 7.14-7.23 (Ar, m, 2.6H), 7.27 (=CH, s, $0.6 \mathrm{H}$ ), $7.30(\mathrm{Ar}, \mathrm{d}, \mathrm{J}=7.8 \mathrm{~Hz}, 0.4 \mathrm{H}), 7.41(=\mathrm{CH}, \mathrm{s}, 0.4 \mathrm{H}), 7.42-7.43$ (Ar, $\mathrm{m}, 0.4 \mathrm{H}$ ), 7.45-7.48 (Ar, m, 0.6H), 7.51 (Ar, d, J = 7.8 Hz, 1.2H), 7.59 (Ar, $\mathrm{dd}, \mathrm{J}=7.8,1.6 \mathrm{~Hz}, 0.4 \mathrm{H}), 7.67-7.69$ (Ar, m, 1.2H), 7.77 (Ar, dd, J = 7.8, $1.6 \mathrm{~Hz}, 0.6 \mathrm{H}) .{ }^{13} \mathrm{C}-\mathrm{NMR}\left(\mathrm{CDCl}_{3}\right), \delta$ (ppm): $(21.33,21.40),(25.84,28.60)$, (44.25, 45.72), (55.68, 55.84), (111.29, 111.49), (120.32, 120.54), 122.16, (123.79, 124.32), (125.49, 125.92), 126.70, (127.27, 127.36) (2C), (128.96, 129.12) (2C), (129.35, 129.41), (129.55, 129.63), (130.65, 131.50), (131.18, 131.35), (132.64, 133.35), (134.69, 135.24), (136.27, 136.86), (139.46, 143.41), (143.68, 143.82), (157.97, 158.63), (191.18, 192.87). LC-MS APCI (+) $[\mathrm{M}+\mathrm{H}]^{+}: 434.3$.

\section{(4-Chlorophenyl)(3-tosyl-2,3-dihydro-1 $\mathrm{H}$-benzo[d]azepin-4-}

yl)methanone (21c). Following the general procedure, $\mathrm{PdCl}_{2}\left(\mathrm{PPh}_{3}\right)_{2}(1.4$ $\mathrm{mg}, 0.0020 \mathrm{mmol}), \mathrm{N}$-tosyl-2-(2-(ethynyl)phenyl)ethanamine (15) (150 $\mathrm{mg}, 0.50 \mathrm{mmol}$ ) and 1-chloro-4-iodobenzene $(5 \mathrm{c})(148 \mathrm{mg}, 0.62 \mathrm{mmol})$ were mixed in $\mathrm{Et}_{3} \mathrm{~N}(1.5 \mathrm{~mL})$ and toluene $(1.0 \mathrm{~mL})$. The mixture was stirred for $6 \mathrm{~h}$ at $110^{\circ} \mathrm{C}$. The crude product was purified through column chromatography (neutral $\mathrm{Al}_{2} \mathrm{O}_{3}, n$-pentane/AcOEt 4:1), obtaining $133 \mathrm{mg}$ (yield $61 \%$ ) of $21 \mathrm{c}$ as two conformational isomers, $s$-trans and $s$-cis, in the molar ratio 64/36. ${ }^{1} \mathrm{H}-\mathrm{NMR}\left(\mathrm{CDCl}_{3}\right), \delta(\mathrm{ppm}): 2.31\left(\mathrm{CH}_{3}, \mathrm{~s}, 0.64 \mathrm{H}\right)$, $2.35\left(\mathrm{CH}_{3}, \mathrm{~s}, 0.36 \mathrm{H}\right), 2.56\left(\mathrm{CH}_{2}, \mathrm{t}, \mathrm{J}=6.3 \mathrm{~Hz}, 1.28 \mathrm{H}\right), 2.87\left(\mathrm{CH}_{2}, \mathrm{t}, \mathrm{J}=\right.$ $6.0 \mathrm{~Hz}, 0.72 \mathrm{H}), 3.71\left(\mathrm{CH}_{2}, \mathrm{t}, \mathrm{J}=6.3 \mathrm{~Hz}, 1.28 \mathrm{H}\right), 3.74\left(\mathrm{CH}_{2}, \mathrm{t}, \mathrm{J}=6.0 \mathrm{~Hz}\right.$, 0.72H), 6.94-6.95 (Ar, m, 0.64H), 6.98-7.00 (Ar, m, 0.36H), 7.05 (=CH, s, 0.64H), 7.07-7.09 (Ar, m, 1.64H), 7.18-7.25 (Ar, m, 2.72H), $7.29(=\mathrm{CH}, \mathrm{s}$, $0.36 \mathrm{H}$ ), 7.40 (Ar, d, J = 7.8 Hz, 0.72H), $7.44(\mathrm{Ar}, \mathrm{d}, \mathrm{J}=8.4 \mathrm{~Hz}, 1.28 \mathrm{H}$ ), 7.53 (Ar, d, J = 7.8 Hz, 1.28H), 7.67 (Ar, d, J = 7.8 Hz, 0.72H), 7.72-7.73 (Ar, m, 0.64H), 7.86-7.88 (Ar, m, 2H). ${ }^{13} \mathrm{C}-\mathrm{NMR}\left(\mathrm{CDCl}_{3}\right), \delta$ (ppm): (26.11, 26.94), (28.79, 29.66), (44.47, 45.56), (116.66, 119.06), (124.38, 125.96), (126.51, 126.96), 127.37 (2C), (128.40, 128.81) (2C), (129.14, 129.37), (129.63, 129.88), 130.03 (4C), (130.39, 130.73), (134.92, 135.16), (136.47, 136.52), (136.67, 137.18), (138.40, 139.27), (141.34, 143.86), (144.26, 144.88), (190.12, 192.34).

LC-MS APCl $(+)[\mathrm{M}+\mathrm{H}]^{+}: 438.2$

4-(3-tosyl-2,3-dihydro-1 H-benzo[d]azepine-4-carbonyl)benzonitrile

(21d). Following the general procedure, $\mathrm{PdCl}_{2}\left(\mathrm{PPh}_{3}\right)_{2}(1.4 \mathrm{mg}, 0.0020$ $\mathrm{mmol}), \quad \mathrm{N}$-tosyl-2-(2-(ethynyl)phenyl)ethanamine (15) (150 mg, 0.50 $\mathrm{mmol})$ and 4-iodobenzonitrile $(\mathbf{5 d})(142 \mathrm{mg}, 0.62 \mathrm{mmol})$ were mixed in $\mathrm{Et}_{3} \mathrm{~N}(1.5 \mathrm{~mL})$ and toluene $(1.0 \mathrm{~mL})$. The mixture was stirred for $6 \mathrm{~h}$ at $110^{\circ} \mathrm{C}$. The crude product was purified through column chromatography (neutral $\mathrm{Al}_{2} \mathrm{O}_{3}, n$-hexane/AcOEt 7:3), obtaining $135 \mathrm{mg}$ (yield $63 \%$ ) of 21d as two conformational isomers, $s$-trans and $s$-cis, in the molar ratio $78 / 22,36 \mathrm{mg}$ (yield $18 \%$ ) of $N$-(2-((4-cyanophenyl)ethynyl)phenethyl)-4methylbenzenesulfonamide (23) and $12 \mathrm{mg}$ (yield 9\%) of 4-(2,3-dihydro$1 \mathrm{H}$-benzo[d]azepine-4-carbonyl)benzonitrile (24).

21d: ${ }^{1} \mathrm{H}-\mathrm{NMR}\left(\mathrm{CDCl}_{3}\right), \delta(\mathrm{ppm}): 2.30\left(\mathrm{CH}_{3}, \mathrm{~s}, 2.34 \mathrm{H}\right), 2.36\left(\mathrm{CH}_{3}, \mathrm{~s}\right.$, $0.66 \mathrm{H}), 2.48\left(\mathrm{CH}_{2}, \mathrm{t}, \mathrm{J}=6.0 \mathrm{~Hz}, 1.56 \mathrm{H}\right), 2.88\left(\mathrm{CH}_{2}, \mathrm{t}, \mathrm{J}=6.0 \mathrm{~Hz}, 0.44 \mathrm{H}\right)$, $3.64\left(\mathrm{CH}_{2}, \mathrm{t}, \mathrm{J}=6.0 \mathrm{~Hz}, 1.56 \mathrm{H}\right), 3.75\left(\mathrm{CH}_{2}, \mathrm{t}, \mathrm{J}=\right.$ 
6.0 Hz, 0.44H), 6.92-6.93 (Ar, m, 0.78H), 6.98-7.00 (Ar, m, 0.22H), 7.03 $(=\mathrm{CH}, \mathrm{s}, 0.78 \mathrm{H}), 7.07-7.08(\mathrm{Ar}, \mathrm{m}, 2 \mathrm{H}), 7.20-7.26(\mathrm{Ar}, \mathrm{m}, 2.44 \mathrm{H}), 7.27$ $(=\mathrm{CH}, \mathrm{s}, 0.22 \mathrm{H}), 7.49(\mathrm{Ar}, \mathrm{d}, \mathrm{J}=7.8 \mathrm{~Hz}, 1.56 \mathrm{H}), 7.68-7.70(\mathrm{Ar}, \mathrm{m}, 1 \mathrm{H})$, 7.73-7.76 (Ar, m, 2H), $7.93(\mathrm{Ar}, \mathrm{d}, \mathrm{J}=8.4 \mathrm{~Hz}, 0.44 \mathrm{H}), 7.96(\mathrm{Ar}, \mathrm{d}, \mathrm{J}=8.4$ $\mathrm{Hz}, 1.56 \mathrm{H}) .{ }^{13} \mathrm{C}-\mathrm{NMR}\left(\mathrm{CDCl}_{3}\right), \delta(\mathrm{ppm}): 21.45,25.88,44.30,115.04$, $118.38,118.42,124.49,127.14,127.25$ (2C), 128.98 (4C), 129.17, $129.52,130.27,131.93(2 \mathrm{C}), 134.91,136.38,142.45,142.62,144.16$, 192.65. LC-MS APCl (+) $[\mathrm{M}+\mathrm{H}]^{+}: 429.3$.

23: ${ }^{1} \mathrm{H}-\mathrm{NMR}\left(\mathrm{CDCl}_{3}\right), \delta$ (ppm): $2.39(3 \mathrm{H}, \mathrm{s}), 3.05(2 \mathrm{H}, \mathrm{t}, \mathrm{J}=7.2 \mathrm{~Hz}), 3.29-$ $3.32(2 \mathrm{H}, \mathrm{m}), 4.69(1 \mathrm{H}, \mathrm{t}, \mathrm{J}=6.0 \mathrm{~Hz}), 7.17(1 \mathrm{H}, \mathrm{d}, \mathrm{J}=7.8 \mathrm{~Hz}), 7.22-7.26$ $(3 \mathrm{H}, \mathrm{m}), 7.28-7.31(\mathrm{~m}, 1 \mathrm{H}), 7.50-7.51(\mathrm{~m}, 1 \mathrm{H}), 7.60(2 \mathrm{H}, \mathrm{d}, \mathrm{J}=8.4 \mathrm{~Hz})$, $7.63(2 \mathrm{H}, \mathrm{d}, \mathrm{J}=8.4 \mathrm{~Hz}) ; 7.68(2 \mathrm{H}, \mathrm{d}, \mathrm{J}=7.8 \mathrm{~Hz}) .{ }^{13} \mathrm{C}-\mathrm{NMR}\left(\mathrm{CDCl}_{3}\right), \delta$ (ppm): $21.48,34.95,43.36,91.65,91.78,111.59,118.45,121.96,126.93$ 126.96 (2C), 127.85, 129.55, 129.66, 132.05 (4C), 132.77, 136.85, 139.97, 143.36. LC-MS APCI (+) $[\mathrm{M}+\mathrm{H}]^{+}: 400.3$.

24: ${ }^{1} \mathrm{H}-\mathrm{NMR}\left(\mathrm{CDCl}_{3}\right), \delta(\mathrm{ppm}): 3.04(2 \mathrm{H}, \mathrm{t}, \mathrm{J}=6.6 \mathrm{~Hz}), 3.62-3.65(2 \mathrm{H}, \mathrm{m})$, $6.34(1 \mathrm{H}, \mathrm{s}), 7.33(1 \mathrm{H}, \mathrm{d}, \mathrm{J}=6.6 \mathrm{~Hz}), 7.42(1 \mathrm{H}, \mathrm{t}, \mathrm{J}=7.6 \mathrm{~Hz}), 7.52(1 \mathrm{H}, \mathrm{t}$, $\mathrm{J}=7.6 \mathrm{~Hz}), 7.77(2 \mathrm{H}, \mathrm{d}, \mathrm{J}=8.4 \mathrm{~Hz}), 7.86(1 \mathrm{H}, \mathrm{d}, \mathrm{J}=8.4 \mathrm{~Hz}), 8.06(2 \mathrm{H}, \mathrm{d}$, $\mathrm{J}=8.4 \mathrm{~Hz}), 12.00(1 \mathrm{H}, \mathrm{s}) .{ }^{13} \mathrm{C}-\mathrm{NMR}\left(\mathrm{CDCl}_{3}\right), \delta(\mathrm{ppm}): 28.13,38.67$, 113.56, 118.68, 125.67, 127.32, 127.41 (4C), 128.46, 128.78, 131.72 , 132.10, 136.70, 144.73, 159.62, 185.90. LC-MS APCl (+) [M+H]+: 275.0.

\section{(4-Aminophenyl)(3-tosyl-2,3-dihydro-1 H-benzo[d]azepin-4-}

yl)methanone (21g). Following the general procedure, $\mathrm{PdCl}_{2}\left(\mathrm{PPh}_{3}\right)_{2}(1.4$ $\mathrm{mg}, 0.0020 \mathrm{mmol}), \mathrm{N}$-tosyl-2-(2-(ethynyl)phenyl)ethanamine (15) (150 $\mathrm{mg}, 0.50 \mathrm{mmol})$ and 1-iodo-4-nitrobenzene $(5 \mathrm{~g})(154 \mathrm{mg}, 0.62 \mathrm{mmol})$ were mixed in $\mathrm{Et}_{3} \mathrm{~N}(1.5 \mathrm{~mL})$ and toluene $(1.0 \mathrm{~mL})$. The mixture was stirred for $6 \mathrm{~h}$ at $110^{\circ} \mathrm{C}$. The crude product was purified through column chromatography (neutral $\mathrm{Al}_{2} \mathrm{O}_{3}, n$-pentane/AcOEt 3:2), obtaining $63 \mathrm{mg}$

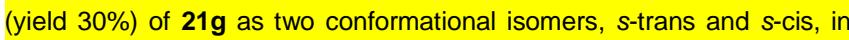
the molar ratio 45/55. ${ }^{1} \mathrm{H}-\mathrm{NMR}\left(\mathrm{CDCl}_{3}\right), \delta(\mathrm{ppm}): 2.29\left(\mathrm{CH}_{3}, \mathrm{~s}, 1.35 \mathrm{H}\right)$, $2.31\left(\mathrm{CH}_{3}, \mathrm{~s}, 1.65 \mathrm{H}\right), 2.65\left(\mathrm{CH}_{2}, \mathrm{t}, \mathrm{J}=6.0 \mathrm{~Hz}, 0.9 \mathrm{H}\right), 2.82\left(\mathrm{CH}_{2}, \mathrm{t}, \mathrm{J}=6.0\right.$ $\mathrm{Hz}, 1.1 \mathrm{H}), 3.72\left(\mathrm{CH}_{2}, \mathrm{t}, \mathrm{J}=6.0 \mathrm{~Hz}, 1.1 \mathrm{H}\right), 3.77\left(\mathrm{CH}_{2}, \mathrm{t}, \mathrm{J}=6.0 \mathrm{~Hz}, 0.9 \mathrm{H}\right)$, $4.25\left(\mathrm{NH}_{2}\right.$, bs, 2H), $6.63(\mathrm{Ar}, \mathrm{d}, \mathrm{J}=8.4 \mathrm{~Hz}, 1.1 \mathrm{H}), 6.65(\mathrm{Ar}, \mathrm{d}, \mathrm{J}=8.4 \mathrm{~Hz}$, 0.9H), 6.93-6.95 (Ar, m, 1H), 6.99-7.00 (Ar, m, 0.55H), $7.06(\mathrm{Ar}, \mathrm{d}, \mathrm{J}=$ $7.8 \mathrm{~Hz}, 0.9 \mathrm{H}), 7.10(=\mathrm{CH}, \mathrm{s}, 0.55 \mathrm{H}), 7.11-7.16(\mathrm{Ar}, \mathrm{m}, 2 \mathrm{H}), 7.19-7.22$ (Ar, $\mathrm{m}, 1 \mathrm{H}), 7.26(=\mathrm{CH}, \mathrm{s}, 0.45 \mathrm{H}), 7.55(\mathrm{Ar}, \mathrm{d}, \mathrm{J}=7.8 \mathrm{~Hz}, 0.9 \mathrm{H}), 7.64$ (Ar, d, J $=7.8 \mathrm{~Hz}, 1.1 \mathrm{H}), 7.69-7.71(\mathrm{Ar}, \mathrm{m}, 0.55 \mathrm{H}), 7.79(\mathrm{Ar}, \mathrm{d}, \mathrm{J}=8.4 \mathrm{~Hz}, 0.9 \mathrm{H})$, $7.86(\mathrm{Ar}, \mathrm{d}, \mathrm{J}=8.4 \mathrm{~Hz}, 1.1 \mathrm{H}) .{ }^{13} \mathrm{C}-\mathrm{NMR}\left(\mathrm{CDCl}_{3}\right), \delta(\mathrm{ppm}):(20.41,20.43)$, (25.35, 27.41), (43.73, 44.69), (112.64, 112.81) (2C), (119.65, 119.71), (123.30, 124.91), (125.53, 125.74); (126.32, 126.54) (2C), (127.59, 128.14), (128.23, 128.47) (2C), (128.26, 128.37), (130.14, 130.28), $(130.20,130.36)(2 \mathrm{C}),(131.14,131.82),(133.80,134.35), \quad(134.99$, 135.65), (138.59, 140.36), (142.56, 142.88), (150.07, 150.61), (189.13, 190.03). LC-MS APCI (+) $[\mathrm{M}+\mathrm{H}]^{+}: 419.2$.

Computational details. Molecular mechanics calculations were run with Spartan'14 (Wavefunction, Inc., Irvine CA, 2014), with standard parameters and convergence criteria. Conformational searches were run with the Monte Carlo algorithm using Merck molecular force field (MMFF), ${ }^{[12]}$ and geometry optimizations were run at the same level of theory.

Supporting Information (see footnote on the first page of this article): Synthesis of precursors $(\mathbf{1}, \mathbf{8 a}, \mathbf{8 b}, \mathbf{1 5})$ and copies of the ${ }^{1} \mathrm{H}-\mathrm{NMR}$ and ${ }^{13} \mathrm{C}-\mathrm{NMR}$ spectra.

\section{Acknowledgements}

This study was supported by the Università di Pisa under PRA 2015 (project No. 2015_0038). The authors are indebted to prof. Gennaro Pescitelli for molecular mechanisc calculations.

Keywords: Synthetic methods / Carbonylation / Cyclisation / Isoindoline / benzoazepine

[1] a) A. J. Kochanowska-Karamyan, M. T. Hamann, Chem. Rev. 2010, 110, 4489-4497; b) K. Speck, T. Magauer, Beilstein J. Org. Chem. 2013, 9, 2048-2078; c) W. Xu, D. J. Gaviab, Y. Tang, Nat. Prod. Rep. 2014, 31, 1474 1487 ;d) P. Kittakoop, C. Mahidol, S. Ruchirawat, Curr. Top. Med. Chem. 2014, 14, 239-252; e) W. Zi, Z. Zuo, D. Ma, Acc. Chem. Res. 2015, 48, 702-711.

[2] a) S. Gauvin, F. Santerre, J.P. Dodelet, Y. Ding, A.R. Hlil, A.S. Hay, J. Anderson, N.R. Armstrong, T.C. Gorjanc, M. D'lorio, Thin Solid Films 1999, 353, 218-222; b) V. Radtke, P Erk, B. Sens, High Performance Pigments, (Ed H. M. Smith), Wiley-VCH Verlag GmbH \& Co. KGaA, Weinheim, 2002, p. 211 230; c) J. O. Escobedo, O. Rusin, S. Lim, R. M. Strongin, Curr. Op. Chem Biol. 2010, 14:64-70; d) N. Karton-Lifshin, E. Segal, L. Omer, M. Portnoy,. R. Satchi-Fainaro, D. Shabat, J. Am. Chem. Soc. 2011, 133, 10960-10965; e) X. Wang, H. Liu, J. Cui, Y. Wu, H. Lu, J. Lu, Z. Liu, W. He, New J. Chem., 2014 38, 1277-1283; f) E. Kim, Y. Lee, S. Lee, S. B. Park, Acc. Chem. Res. 2015, 48, 538-547; g) W. Zhong C. Xu B. Xiao, L. Fan, H. Wu, B. Zhang, W. Yang, Polym. Sci. Ser. B 2016, 1-7.

[3] a) G. R. Humphrey, J. T. Kuethe, Chem. Rev. 2006, 106, 2875-2911; b) K. Kruger, A. Tillack, M. Beller, Adv. Synth. Catal. 2008, 350, 2153-2167; c) J. Barluenga, F. Rodriguez, F. J. Fananas, Chem. Asian J. 2009, 4, 1036 1048; d) J. J. Song, J. T. Reeves, D. R. Fandrick, Z. Tan, N. K. Yee, C. H. Senanayake, ARKIVOC 2010, 390-449; e) S. Sadjadi, M. M. Heravi, Tetrahedron 2011, 67, 2707-2752; f) S. Cacchi, G. Fabrizi, A. Goggiamani, Org. Biomol. Chem., 2011, 9, 641-652; g) S. Cacchi, G. Fabrizi, A Goggiamani, Org. Reac. 2012,76, 281-534; h) A. Varela-Fernández, J. A Varela, C. Saá, Synthesis 2012; 44, 3285-3295; i) M. Shiri, Chem. Rev. 2012 112, 3508-3549; j) M. Platon, R. Amardeil, L. Djakovitchb, J. C. Hierso, Chem. Soc. Rev., 2012, 41, 3929-3968; k) S. Cacchi, G. Fabrizi, A. Goggiamani, C. Molinaro, R. Verdiglione, J. Org. Chem. 2014, 79, 401-407; I) S. Cacchi, G. Fabrizi, A. lazzetti, C. Molinaro, R. Verdiglione, A. Goggiamani, Adv.Synth. Catal. 2015, 357,1053 -1059; m) S. Cacchi, G. Fabrizi, A. Goggiamani, A. lazzetti, R. Verdiglione, Tetrahedron 2015, 71, 9346-9356.

[4] a) A. S. Dudnik, V. Gevorgyan, Catalyzed Carbon-Heteroatom Bond Formation. (Ed. A. K. Yudin) WILEY-VCH Verlag GmbH, Weinheim, 2011, pp. 318-383; b) K. C. Majumdar, P. Debnath, N. De; B. Roy, Current Organic Chemistry, 2011, 15, 1760-1801; c) T. S. A. Heugebaert, B. I. Roman, C. V. Stevens, Chem. Soc. Rev., 41, 2012, 5626-5640.

[5] a) T. Berg, S. B. Cohen, J. Desharnais, C. Sonderegger, D. J. Maslyar J. Goldberg, D. L. Boger, P. K. Vogt, Proc. Nat. Acad. Sci. USA 2002, 99, 3830-3835; b) S. Van Goethem a , P. Van der Veken, V. Dubois, A. Soroka, A. M. Lambeir, X. Chen, A. Haemers, S. Scharpé, I. De Meester, K. Augustyns, Bioorg. Med. Chem. Lett. 2008, 18, 4159-4162; c) A. J. Woodhead, H. Angove, M. G. Carr, Gi. Chessarill, M. Congreve, J. E. Coyle, J. Cosme, B. Graham, P. J. Day, R. Downham, L. Fazal, R. Feltell, Eva Figueroa, M. Frederickson, J. Lewis, R. McMenamin, C. W. Murray, M. A. O'Brien, L. Parra, S. Patel, T. Phillips, D. C. Rees, S. Rich, D. M. Smith, G. Trewartha, M. Vinkovic, B. Williams, A. J. A. Woolford, J. Med. Chem., 2010, 53, pp 5956-5969.

[6] a) S. Ruchirawata, P. Sahakitpichana, Tetrahedron Lett. 2000, $418007-$ 8010; b) D. L. Boger, J. Desharnais, K. Capps, Angew. Chem. Int. Ed. 2003 42, 4138-4176; c) M. Tsubakiyama, Y. Sato, M. Mori, Heterocycles, 2004, 64, 27-31; e) A. L. Auvinet, M. Ez-Zoubir, S. Bompard, M.R. Vitale, J. Brown, V. Michelet, V. Ratovelomanana-Vidal, ChemCatChem 2013, 5, 2389-2394; f) A. L. Auvinet, M. Ez-Zoubir, M. R. Vitale, J. A. Brown, V. Michelet, V. Ratovelomanana-Vidal, ChemSusChem 2012, 5, 1888 - 1891; d) E. 
Elamparuthi, S. Sarathkumar, S. Girija, V. Anbazhagan, Tetrahedron Lett. 2014, 55, 3992-3995.

[7] a) L. A. Aronica, L. Giannotti, S. Giuntini, A. M. Caporusso, Eur. J. Org.

Chem. 2014, 6858-6862; b) L. A. Aronica, L. Giannotti, G. Tuci, F. Zinna, Eur. J. Org. Chem. 2015, 4944-4949.

[8] J. E Baldwin, J. Chem. Soc., Chem. Commun., 1976, 734-736

[9] a) C. Kaiser, P. A. Dandridge, E. Garvey, R. A. Hahn, P. E. Setler, L. S. Bass, J. Clardy, J. Med. Chem., 1982, 25, 697-703; b) DeMarinis, R. M.; Krog, A. J.; Shah, D. H.; Lafferty, J.;Holden, K. G.; Hieble, J. P.; Mathews, W. D.; Regan, J. W.; Lefkowitz, R. J.; Caron,M. G. J. Med. Chem., 1984, 27, 918921; c) Tietze, L. F.; Schimpf, R., Synthesis, 1993, 876-880; d) W. H. Frishman, J. Clin. Pharamacol., 1998, 38, 2-13; e) Foubelo, F.; Gomez, C.; Gutierrez, A.; Yus, M.J., Heterocycl. Chem,. 2000, 37, 1061-1064; f) Toda, J.; Ichikawa, T.; Saitoh, T.; Horiguchi, Y.; Sano, T., Heterocycles, 2000, 53, 20092018; g) Worden,S. M.; Mapitse, R.; Hayes, C. J, Tetrahedron Lett., 2002, 43 , 6011-6014; h) O. Krull, B. Wunsch, Bioorg. Med. Chem., 2004, 12, 1439-1442 i) P. A. Donets, E. V. Van der Eycken, Org. Lett., 2007, 9, 3017-3020; j) S. M. Husain, R. B. FrohlichWunsch, Tetrahedron:Asymmetry, 2008, 19, 1613-1616; k) M. F. Dalence-Guzman, M. Berglund, S. Skogvallc, O. Sternera, Bioorg.Med. Chem. 2008, 16, 2499-2512; I) S. M. Husain, R. Frohlich, D. Schepmann, B. Wunsch, J. Org.Chem., 2009, 74, 2788-2793; m) D. Garcia, F. Foubelo, M. Yus, Eur. J. Org.Chem., 2010, 2893-2902.

[10] a) H. A. Stefani, A. S. Guarezemini, R. Cella, Tetrahedron, 2010, 66 7871-7918; b) S. Perrone, F. Bona, L. Troisi, Tetrahedron, 2011, 67, 73867391; c) A. Stolle, B. Ondruschka Pure Appl. Chem., 2011, 83, 1343-1349; c) S. Wang, D. Hu, W. Hua, J. Gu, Q. Zhang, X. Jia, K. Xi RSC Adv., 2015, 5, 53935-53939; d) M. Guo, B. Chen, M. Lv, X. Zhou, Y. Wen, X. Shen, Molecules, 2016, 21, 606-612.

[11] a) X-F. Wu, H. Neumann, M. Beller, Chem. Soc. Rev., 2011, 40, 4986-5009; b) X.-F. Wu, H. Neumann, ChemCatChem 2012, 4, 447-458; c) X.-F. Wu, H. Neumann, M. Beller, Chem. .Rev. 2013,113, 1-35; d) X.F. Wu, H. Neumann, M. Beller, ChemSusChem 2013, 6, 229-241; e) X. Qi, L.-B. Jiang, C.-L. Li, R. Li, X.-F. Wu* Chem. Asian J. 2015, 10, 18701873; f) W. Li, X.-F. Wu, Org. Biomol. Chem. 2015, 13, 5090-5093; g) X.F. Wu, Chem. Eur. J. 2015, 21, 12252-12265; h) X.-F. Wu, H. Neumann, M. Beller ChemSusChem 2016, 9, 2279-2283; i) X.-F. Wu, RSC Adv. 2016, 6, 83831-83837; j) X. Qi, R. Li, X.-F. Wu RSC Adv. 2016, 6, 62810-62813; k) L.-B. Jiang, X. Qi, X.-F. Wu Tetrahedron Lett. 2016, 57, 3368-3370; I) F. Zhu, Y. Li, Z. Wang, X.-F. Wu Catal. Sci. Technol. 2016, 6, 2905-2909.

[12] T. A.Halgren, J. Comput. Chem., 1996, 17, 490-519. 


\section{FULL PAPER}

A one-step synthesis of functionalised isoindolines and

dihydrobenzoazepines was developed through copper-free, palladiumcatalysed cyclocarbonylative Sonogashira reactions between tosylamides and iodoarenes.

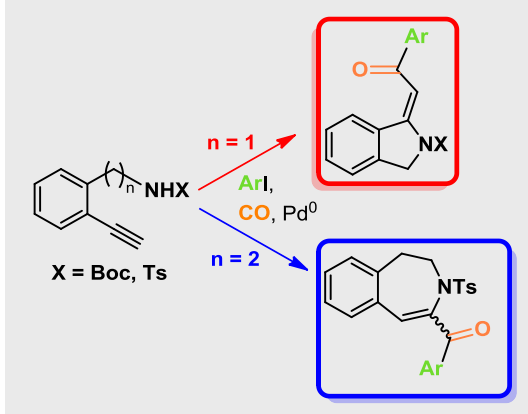

Cyclocarbonylative cross coupling

Laura Antonella Aronica*, Gianluigi Albano, Luca Giannotti, Elisa Meucci

Page No. - Page No.

A new synthesis of $\mathrm{N}$-heteroaromatic compounds via cyclocarbonylative Sonogashira reactions 